\title{
Review Article \\ Occurrence of Fungi and Mycotoxins in Fish Feeds and Their Impact on Fish Health
}

\author{
Esther Marijani (iD, ${ }^{1}$ Emmanuel Kigadye, ${ }^{1}$ and Sheila Okoth ${ }^{2}$ \\ ${ }^{1}$ Open University of Tanzania, P.O. Box 23409, Dar es Salaam, Tanzania \\ ${ }^{2}$ University of Nairobi, School of Biological Science, P.O. Box 30197-00100, Nairobi, Kenya \\ Correspondence should be addressed to Esther Marijani; esthermarijani@gmail.com
}

Received 8 July 2019; Accepted 1 October 2019; Published 11 November 2019

Academic Editor: Joseph Falkinham

Copyright (C) 2019 Esther Marijani et al. This is an open access article distributed under the Creative Commons Attribution License, which permits unrestricted use, distribution, and reproduction in any medium, provided the original work is properly cited.

\begin{abstract}
The rapid population growth in developing countries has led to strong pressure on capture fisheries. However, capture fisheries have reached their maximal limits of fish production and are supplemented by farmed fish. The growth in aquaculture has led to high demand for fish feeds, which play a very important role in fish nutrition and health. Use of animal protein in fish feeds is expensive; hence, a majority of farmers from developing countries use local feed ingredients from plant origin as a source of dietary protein. However, these ingredients of plant origin provide the best natural substrates for fungi, which can be easily accompanied by mycotoxin development under suitable conditions. The locally made feed comprises ingredients such as soybeans, cottonseed cake, and wheat and maize bran which are mixed together and ground after which the compounded feed is pelleted and stored. Among the ingredients, maize and oilseeds are more susceptible for mycotoxigenic fungi compared to other ingredients. The outcomes of mycotoxin contamination in fish feeds are not different from other animal species intended for human consumption, and they are directly associated with production losses, particularly decreased weight gain and feed conversion, impaired immune system and reproductive performance, and increased fish mortality. Fish may also carry mycotoxin residues along the food chain, thus compromising human health. Hence, it is important to ensure the control of mycotoxin contamination in fish feeds, especially during the production and storage.
\end{abstract}

\section{Introduction}

Fish production in 2012 surpassed 158 million metric tons, whilst the value of international fish trade added up to USD 129 billion [1]. Aquaculture is the world's fastest growing food production sector for more than four decades, whereas an increasingly large share of fish entering the global markets is derived from aquaculture [2]. Aquaculture production in Africa significantly increased from 646,182 to $1,710,910$ million metric tons; as a matter of fact, fish and shrimp production in Africa has already grown by approximately $400 \%$ [3]. This rapid increase has been due to a decline in fish production from capture systems and increased awareness of the nutritional importance of fish [4]. With the rapid growth in aquaculture, demand for fish feeds is expected to continue increasing proportionately [5].
Fish feed is an essential part of the aquaculture industry and comprises $40-50 \%$ of the total production cost in intensive culture systems [6]. It also has an important contribution to the production of fish feed since it tends to affect the quality of eggs [7]. A majority of fish farmers in developing countries use locally made fish feeds or commercially imported feeds for Nile tilapia (Oreochromis niloticus) and African catfish (Clarias gariepinus) production. The imported fish feed is more expensive than the locally made ones. Hence, many fish farmers use locally made fish feed usually produced and stored in large quantities in order to reduce production costs and increase profit margins [8]. The locally made feeds are usually from locally available plant and animal wastes like rice, maize and wheat bran, blood meal, cottonseed cake and sunflower seedcakes, and soybeans and cassava [9]. These ingredients can be ground 
manually and mixed in a hand-operated mixer and then made into pellets using a pelleting machine. Such ingredients are often subjected to contamination by molds during preharvest and/or due to poor storage conditions [10]. Prolonged storage and high temperature and humidity conditions are some of the factors that facilitate fungal development and production of attendant mycotoxins, compromising feed quality that can adversely affect the health of animals and humans [11].

Some molds are capable of producing mycotoxins, and some of these mycotoxins can cause some degree of acute toxicity when given in high amounts and are the potential carcinogens [12]. Aspergillus, Fusarium, and Penicillium are the three most important genera of toxigenic fungi in the tropics [13]. The presence of toxigenic fungi, some producing mycotoxin in farmed fish has increased in recent years owing to the increasing use of plant materials as components for fish feeding [5]. Contamination of fish feeds by mycotoxins and the possible transfer of these toxins into farmed fish and fish-derived products for human consumption remain a serious food safety concern [14].

Around 300-400 mycotoxin types are known to date [15], but the most important in tropical countries are aflatoxins (AFs) $\left(A_{1} B_{1}, B_{2}, G_{1}\right.$, and $G_{2}$ ) and fumonisins (FBs) $\left(\mathrm{FB}_{1}, \mathrm{FB}_{2}\right.$, and $\left.\mathrm{FB}_{3}\right)$ [16]. In addition to $\mathrm{AFs}$ and $\mathrm{FBs}$, ochratoxin A (OTA) and trichothecenes (THs) are also important [17].

Mycotoxin contamination has been implicated with a reduction in fish productivity, anemia, hemorrhaging, liver impairment, weight loss, increased vulnerability to secondary infectious diseases, reduced reproductive capacity, and even mortality [18-21], resulting in serious economic losses [22, 23].

Since aquaculture is a growing sector in a majority of the developing countries, especially in Africa, the aim of this review is to give an overview of fungal and mycotoxin contamination of fish feed, feed ingredients, and their effects on fish health.

\section{Feed Consumption in Farmed Fish}

Fish feed is the major cost item in intensive farming systems, and they represent 50 to 70 percent of fish farmers' production costs [24]. Requirements for intensive aquaculture are high-quality animal protein, lipid, and other essential nutrients [25]. In order to reduce the feed cost, several efforts have been made to replace the expensive feed ingredients. Incorporating vegetable oil, increasing levels of plant ingredients, and reduction in the level of costly fish meal are appropriate husbandry practices that have been adopted to reduce maintenance costs (particularly feed costs). Zhao et al. [26] reported that fish meal can be completely replaced by soy protein concentrate by increasing feeding frequency for Nile tilapia less than 2 grams. A combination of $76 \%$ rice bran and $24 \%$ fish meal, which is a mix of dried freshwater shrimp Caridina sp., or maize bran, sometimes with the addition of some "dagaa" Rastrineobola argentea meal, shows good growth performance on fish [8, 27]. Despite their higher nutritional values, plant ingredients in fish feeds have a higher potential of being contaminated with toxigenic fungi than animal ingredients. This potential is further increased in tropical and subtropical conditions due to storage under humid and hot conditions [28].

\section{Occurrence of Mycotoxigenic Fungi in Fish Feeds and Ingredients}

Fungi are ubiquitous in the environment, being found in water and suitable organic nutrients when appropriate temperature conditions prevail [17]. They have been reported to occur in food and feed worldwide with some of them capable of producing a wide array of mycotoxins. Four major genera stand out: Alternaria, Aspergillus, Fusarium, and Penicillium [17]. Among the genus Aspergillus, A. flavus and A. parasiticus are the major aflatoxin producers that are likely harmful to animals or humans [11]. Several A. flavus strains may or may not produce either aflatoxin $B_{1}$ or $B_{2}$ [11]. Secondary metabolites such as sterigmatocystin, cyclopiazonic acid (CPA), kojic acid, beta-nitropropionic acid, aspertoxin, aflatrem, and aspergillic acid are other toxic compounds also produced by A. flavus [11]. Aspergillus parasiticus produces aflatoxins $G_{1}$ and $G_{2}$, in addition to aflatoxins $\mathrm{B}_{1}$ and $\mathrm{B}_{2}$, but does not produce CPA [11]. Aspergillus ochraceus and $A$. carbonarius are the main producers of ochratoxin A (OTA), and they are commonly found in grapes, dried vine fruits, wine, and coffee [29]. However, only a few strains of $A$. niger are capable of producing OTA [30]. Aspergillus fumigatus is the main producer of genotoxic and cytotoxic mycotoxins, like gliotoxin [31]. Some other species of Aspergillus, such as A. tamarii and A. versicolor, produce $\mathrm{CPA}$ and fumuclavine $\mathrm{A}$ and have been responsible for "kodua" poisoning [32]. Kodua is known for poisoning that causes tremors, sleepiness, and giddiness [32, 33].

Aspergillus species are ubiquitous in tropical environments and are predominantly isolated in food and feed from the tropics [11]. Fish feeds are frequently contaminated by Aspergillus species (Table 1). Several studies performed in tropical countries reported that A. flavus and A. parasiticus are the major dominant species isolated from fish feed [33, 37, 39, 40]. Fallah et al. [39] and Hassan et al. [44] found that $47.5 \%$ and $70 \%$ of fish feed from Egypt and Iran, respectively, were contaminated by A. flavus. Fish feeds from Brazil and East Africa were contaminated by A. flavus at 35\% and $54.5 \%$, respectively $[35,40]$. Aspergillus tamarii were isolated at a frequency of $9.1 \%$ and $8 \%$ in fish feeds from East Africa and Iran, respectively. Aspergillus niger (6\%, 13.9\%, $36 \%$, and $39.1 \%$ ) and $A$. ochraceus $(10.2 \%)$ as the potential ochratoxigenic fungi were isolated from fish feed from East Africa, Iran, Portugal, and Brazil [10, 35, 39, 40]. Other Aspergillus species commonly isolated from fish feeds are $A$. versicolor, A. fumigatus, A. candidus, A. glaucus, and A. oryzae $[35,37,39,40]$. Table 1 compares data from previous studies on the most frequently isolated fungi from fish feeds and their ingredients.

Fusarium species are destructive pathogens on cereal crops and other commodities and produce some of the most commonly encountered mycotoxins including the trichothecenes and fumonisins in feeds [16]. Fusarium 
TABLE 1: Frequently isolated fungi from fish feeds and feed ingredients from previous studies.

\begin{tabular}{|c|c|c|c|c|c|}
\hline Source & Country & $\begin{array}{l}\text { Sample } \\
\text { size }\end{array}$ & Common isolates & $\begin{array}{l}\text { Frequency of } \\
\text { isolation (\%) }\end{array}$ & References \\
\hline \multirow{7}{*}{ Tilapia feeds } & \multirow{7}{*}{ Egypt } & \multirow{7}{*}{25} & A. flavus* & 48 & \multirow{7}{*}{ Mohammed et al. [34] } \\
\hline & & & A. niger & 40 & \\
\hline & & & A. fumigatus & 8 & \\
\hline & & & A. ochraceus & 4 & \\
\hline & & & Penicillium sp., & 40 & \\
\hline & & & Cladosporium sp. & 8 & \\
\hline & & & Candida sp. & 40 & \\
\hline \multirow{7}{*}{ Fish feeds and ingredients } & \multirow{7}{*}{$\begin{array}{c}\text { East } \\
\text { Africa }\end{array}$} & \multirow{7}{*}{52} & A. flavus* & 54.5 & \multirow{7}{*}{ Marijani et al. [35] } \\
\hline & & & A. tamarii & 9.1 & \\
\hline & & & Mucorsp. & 9 & \\
\hline & & & Phoma sp. & 6.1 & \\
\hline & & & A. niger & 6 & \\
\hline & & & E.rubrum & 3 & \\
\hline & & & P. chrysogenum & 3 & \\
\hline \multirow{5}{*}{$\begin{array}{l}\text { Commercial and formulated fish } \\
\text { feeds }\end{array}$} & \multirow{5}{*}{ Kenya } & \multirow{5}{*}{121} & Asperigillus sp. & 50.5 & \multirow{5}{*}{ Njagi [36] } \\
\hline & & & Mucor sp.* & 56 & \\
\hline & & & Rhizopus sp. & 49.5 & \\
\hline & & & Saprolegnia sp. & 42.5 & \\
\hline & & & Penicillium sp. & 31 & \\
\hline \multirow{4}{*}{ Fish feeds and ingredients } & \multirow{4}{*}{ Brazil } & \multirow{4}{*}{54} & Penicillium sp.* & 83.3 & \multirow{4}{*}{ Gonçalves-Nunes et al. [37] } \\
\hline & & & Aspergillus sp. & 66.7 & \\
\hline & & & Rhizopus sp. & 23.3 & \\
\hline & & & Cladosporium sp. & 20 & \\
\hline \multirow{8}{*}{ Rainbow trout feed } & \multirow{8}{*}{ Argentina } & & $\begin{array}{l}\text { Cladosporium } \\
\text { cladosporioides* }\end{array}$ & 53.6 & \\
\hline & & & Eurotium repens & 21.4 & \\
\hline & & & Eurotium rubrum & 14.3 & \\
\hline & & 28 & Mucorsp. & 7.1 & Greco et al. [38] \\
\hline & & & A. versicolor & 3.6 & \\
\hline & & & P. crustosum & 3.6 & \\
\hline & & & P. expansum & 3.6 & \\
\hline & & & P. chrysogenum & 3.6 & \\
\hline & & & A. flavus* & 47.3 & \\
\hline & & & A. parasiticus* & 16.1 & \\
\hline & & & A. niger & 13.9 & \\
\hline & & & A. ochraceus & 10.2 & \\
\hline & & & A. fumigates & 9 & \\
\hline & & & A. versicolor & $<5$ & \\
\hline & & & A. carbonarius & $<5$ & \\
\hline Fish feeds & Iran & 86 & A. nomius & $<5$ & Fallah et al. [39] \\
\hline & & & A.ustus & $<5$ & \\
\hline & & & Fusarium sp. & 26.2 & \\
\hline & & & Eurotium sp. & 10 & \\
\hline & & & Penicillium sp. & 41.5 & \\
\hline & & & Mucor sp. & $<10$ & \\
\hline & & & Cladosporium sp. & $<5$ & \\
\hline & & & Alternaria sp. & $<5$ & \\
\hline & & & Cladosporium sp.* & 85 & \\
\hline & & & P. citrinum $^{*}$ & 71 & \\
\hline & & & A. flavu & 35 & \\
\hline & & & A. niger & 36 & \\
\hline Fish feed & Brazil & 60 & Eurotium sp. & 20 & Barbosa et al. [40] \\
\hline & & & Wallemia & 40 & \\
\hline & & & Aureobasidium & 10 & \\
\hline & & & Mucor, and & 10 & \\
\hline & & & Nigrospora sp. & $<10$ & \\
\hline
\end{tabular}


TABle 1: Continued.

\begin{tabular}{|c|c|c|c|c|c|}
\hline Source & Country & $\begin{array}{l}\text { Sample } \\
\text { size }\end{array}$ & Common isolates & $\begin{array}{l}\text { Frequency of } \\
\text { isolation (\%) }\end{array}$ & References \\
\hline Fish feeds & Brazil & 36 & $\begin{array}{c}\text { A. flavus* } \\
\text { A. fumigates } \\
\text { A. terreus } \\
\text { A. candidus } \\
\text { A. oryzae } \\
\text { A. penicillioides } \\
\text { Eurotium sp. } \\
\text { Penicillium sp. } \\
\text { Cladosporium sp. } \\
\text { Fusarium sp. }\end{array}$ & $\begin{array}{c}60.47 \\
6.98 \\
2.32 \\
2.32 \\
6.98 \\
2.32 \\
18.61 \\
19.18 \\
16.44 \\
8.22\end{array}$ & Filho et al. [41] \\
\hline Tilapia feed & Mexico & 30 & $\begin{array}{l}\text { Aspergillus flavus* } \\
\text { Fusarium sp. }\end{array}$ & $\begin{array}{l}6.7 \\
6.7 \\
\end{array}$ & $\begin{array}{c}\text { Rodriguez-Cervantes et al. } \\
{[42]}\end{array}$ \\
\hline Sea bass feeds & Portugal & 87 & $\begin{array}{l}\text { Aspergillus niger* } \\
\text { Aspergillus glaucus } \\
\text { Penicillium sp. } \\
\text { Cladosporium sp. } \\
\text { Fusarium sp. }\end{array}$ & $\begin{array}{l}39.1 \\
29.9 \\
28.7 \\
28.7 \\
25.3\end{array}$ & Almeida et al. [10] \\
\hline Rainbow trout feed & Iran & & $\begin{array}{c}\text { A. flavus* } \\
\text { A. niger } \\
\text { A. ochraceus } \\
\text { A. fumigates } \\
\text { A. clavatus } \\
\text { Penicillium sp. } \\
\text { Absidia sp. } \\
\text { Mucor sp. } \\
\text { Alternaria sp. }\end{array}$ & $\begin{array}{c}60.66 \\
19.67 \\
1.0 \\
2.0 \\
1.0 \\
14.0 \\
12.0 \\
2.0 \\
2.0\end{array}$ & Alinezhad et al. [43] \\
\hline Fish feeds & Egypt & 50 & $\begin{array}{c}\text { A. flavus* } \\
\text { A. niger } \\
\text { A. ochraceus } \\
\text { A. candidus } \\
\text { Penicillium sp. } \\
\text { Mucor sp. } \\
\text { Cladosporium sp. } \\
\text { Rhizopus sp. }\end{array}$ & $\begin{array}{c}56.0 \\
4.0 \\
2 \\
8.0 \\
22.0 \\
50.0 \\
2.0 \\
4.0\end{array}$ & Hassan et al. [44] \\
\hline
\end{tabular}

${ }^{*}$ The most commonly isolated species.

verticillioides is ubiquitous in maize and produces FBs, which are generally more prevalent when crops are under drought stress or suffer excessive insect damage [45]. Fusarium graminearum is the main producer of the deoxynivalenol (DON) and estrogenic compound zearalenone (ZEN) [46]. This species is pathogenic on maize, wheat, and barley and produces these toxins whenever it infects these grains before harvest. Aspergillus niger also produces FBs, and several commodities may be affected [30]. The most common fungi associated with maize which is the common ingredient in fish feeds are Fusarium verticillioides and Fusarium proliferatum. A study on the infections of Fusarium sp. in feed ingredients was done by Ivić et al. [47] and found that the dominant species were $27 \%$ of F. graminearum isolated on wheat, $83 \%$ of $F$. verticillioides isolated on maize, and $34 \%$ of F. sporotrichioides isolated on soybean. The authors of this study concluded that the risk of contamination with Fusarium toxins is higher for maize and wheat than for soybean. Fusarium species appear to be uncommon to fish feeds as they were isolated in a very small percentage but may cause adverse effects to fish $[10,37,39,42]$.
Some Penicillium species are mycotoxin producers and can negatively affect the health of humans and animals [48]. Penicillium verrucosum produces OTA but occurs only in cool temperate climates, where it infects small grains like wheat and barley [48] and not commonly isolated in tropical areas. Penicillium citrinum is a species where citrinin toxin was first isolated, but the toxin has subsequently been identified to be produced by several Penicillium and Aspergillus species [49]. No information is available on the contamination of citrinin in fish feeds; however, its producer P. citrinum has been isolated from fish feeds [37, 40].

Penicillium expansum, Aspergillus, Penicillium, and Paecilomyces fungal species produce patulin, whereas ergot alkaloids are compounds produced as a toxic mixture of alkaloids in the sclerotia of the species of Claviceps [50]. Penicillium expansum is particularly linked with a range of moldy fruits and vegetables, especially in rotting apples and figs while the species of Claviceps are common pathogens of several grass species. Penicillium expansum occurs best in wet, cool $\left(<25^{\circ} \mathrm{C}\right)$ environments, and the growth rate was the fastest at a relative humidity of $90 \%$ [50]. Penicillium 
expansum has been isolated in fish feeds, and the use of vegetables as feed ingredients could be the reason for the presence of this species in the finished fish feeds [38].

Penicillium crustosum and P. commune are closely related and produce CPA and roquefortine C (ROQ-C) [51]. These species were infrequently encountered in fish feeds [38]. Penicillium chrysogenum is also a ROQ-C producer and had been isolated in fish feeds $[35,38]$. Other Penicillium species which are isolated in fish feeds are Penicillium glabrum, $P$. nalgiovense, $P$. corylophilum, $P$. implicatum, and $P$. restrictum $[37,38,41]$.

The genus Eurotium is also an important mycotoxin producer and grow exceptionally well at low water activities [52]. Most of the Eurotium species are of special interest to feed mycology due to their xerophilic physiology; many isolates are able to grow at water activities below 0.75 , and some isolates are able to grow at values as low as $0.64 a_{w}$ [53]. Eurotium amstelodami, E. repens, and E. rubrum reported to produce aflatoxin $[23,38]$, and ochratoxin $A$ is produced by $E$. amstelodami [23]. Although most of the studies on fish feed mycobiota have been concentrated on the presence of mycotoxigenic genera Aspergillus, Fusarium, and Penicillium, Eurotium sp. have as well reported as frequent contaminants $[38,39,41]$. Commonly, Eurotium species isolated from fish feeds are E. repens and E. rubrum $[35,38]$. Eurotium rubrum were isolated with a frequency of $25 \%$ and $3 \%$, while E. repens (21.4\%) were isolated from fish feed from East Africa and Argentina. Since some of the Eurotium species produce aflatoxin and OTA, their presence in fish feeds could affect fish health and cause serious economic losses.

The commonly used raw ingredients in the manufacturing of fish feeds are maize, rice, wheat bran, soybean, sunflower seed cake, and cottonseed cake, which are highly susceptible to mycotoxin-producing fungi $[17,54,55]$. Several mycotoxigenic fungi had been isolated from ingredients used for fish feed from different fish farms around the world $[28,35,36]$. The presence of these mycotoxigenic fungi in the ingredients might also cause the formation of mycotoxin in the finished fish feeds [35, 38, 40]. Aspergillus flavus was the dominant fungal species isolated from maize bran, cottonseed cake, sunflower oil seed cake, and cassava; however, soybean samples were the least contaminated by mycotoxigenic fungi [35]. In another survey conducted in Brazil, soybean bran intended for fish feeds were contaminated by A. flavus (61.5\%), P. citrinum (81.8\%), and A. parasiticus (7.7\%) [37]. Aspergillus flavus was the dominant species isolated from maize bran (50\%), and other cereals $(66.6 \%)$ were designated for fish feed from Brazil. Other fungal species isolated at higher frequencies from maize bran and other cereals were P. citrinum (50\% and $90.9 \%$ ) and $A$. parasiticus (16.7\%), respectively [37].

Factors like high temperature and relative humidity, together with inappropriate handling and storage practices increase the likelihood of the growth of mycotoxigenic fungi. In addition, storage practices in most developing countries are poor, which make them more vulnerable to fungal contamination [56]. Also, insect infestation can cause heating and generation of moisture. For the cereal grain, an increase in temperature is expected due to respiration, which may likewise occur due to insect or fungal activity. Heating results in moisture condensation in cool areas inside the grain mass [57]. As a result of this, further fungal growth and insect infestation are encouraged. Normally, the standard moisture content required for most cereals often used as feed ingredients should be $14 \%$ before storage [58]. Therefore, it is very important to utilize feed ingredients which have moisture content at or below the safe level of 13\% [58]. Aeration with cool air may also help to protect the stored ingredients against fungal development [59].

\section{Mycotoxin Contamination in Fish Feed and Feed Ingredients}

Plant proteins such as oilseeds are excellent alternatives to animal proteins in fish feeds because they are less expensive and are more abundant in many parts of the world [5]. Diets for Nile tilapia and warm water species such as carp and channel catfish are predominantly formulated using high amounts of grains and plant proteins, and as such, the feeds are at high risk to contamination by mycotoxins [60]. Cereals are common ingredients used in fish feeds and like the oilseeds, they are the main point of entry for many mycotoxins in humans and fish dietary systems, particularly in Africa [35]. Bran, which is also a common ingredient in fish feed, is usually derived from any cereal grains such as rice, maize, wheat, oats, barley, rye, and millet during the dry milling process [61]. Unfortunately, this dry milling is not likely to destroy mycotoxins. Mycotoxins are generally concentrated in the bran and outer layers of grains but are less in the endosperm [62]. This suggests that bran or wholemeal grains have the potential to contain higher concentrations of certain mycotoxins than those manufactured from flours or grits milled from the grain endosperm [61]. The use of mycotoxin contaminated bran and other ingredients provide an avenue for the finished fish feed to contain similar mycotoxins posing a health hazard in fish.

4.1. Occurrence of Aflatoxin. The incidences of aflatoxin contamination in fish feed have been reported in many countries of the world especially in the tropical and subtropical regions as shown in Table 2. Therefore, this means fish feed in both tropical and subtropical regions are more prone to aflatoxin contamination compared to the temperate regions [68]. The recommended regulatory limit for aflatoxin in fish feeds is $20 \mu \mathrm{g} \cdot \mathrm{kg}^{-1}$ [66], but a majority of samples from tropical countries are above this limit $[35,39,40]$.

In the study of Marijani et al. [35], levels of mycotoxins in fish feeds and feed ingredients from fish farms, imported fish feeds, and feeds made by local feed millers in East Africa were analyzed. Results obtained revealed that aflatoxin contamination was higher in feed processed at farm level in terms of incidence rate (64.3\%), feed ingredients (50\%), and local commercial feed mills (35.7\%), but not in imported feed. Inclusion of antifungal agents in imported feeds to prevent fungal growth during prolonged and varied storage conditions in farms might be a possible reason for the 
TABLE 2: Mycotoxin levels $\left(\mu \mathrm{g} \cdot \mathrm{kg}^{-1}\right)$ in fish feed from developing countries.

\begin{tabular}{|c|c|c|c|c|c|c|c|c|c|c|c|c|}
\hline \multirow{2}{*}{ Source } & \multirow{2}{*}{ Country } & \multirow{2}{*}{$\begin{array}{l}\text { Sample } \\
\text { size }\end{array}$} & \multicolumn{8}{|c|}{ Mycotoxin contamination* } & \multirow{2}{*}{$\mathrm{PL} \%^{+}$} & \multirow{2}{*}{ Reference } \\
\hline & & & $\mathrm{AF}$ & FB & DON & OTA & NIV & $\mathrm{AOH}$ & $\mathrm{T}-2$ & ZEN & & \\
\hline Tilapia feeds & Egypt & 25 & $<\mathrm{LOD}$ & na & na & na & na & na & na & na & 0 & $\begin{array}{l}\text { Mohamed et al. } \\
\text { [34] }\end{array}$ \\
\hline $\begin{array}{l}\text { Fish feeds } \\
\text { processed at } \\
\text { farm level }\end{array}$ & $\begin{array}{c}\text { East } \\
\text { Africa }\end{array}$ & 52 & 126 & 755.4 & 2834.6 & nd & 732.5 & 91.3 & $<\mathrm{LOD}$ & na & $\begin{array}{l}48(\mathrm{AF}), 0 \\
(\mathrm{FB}), 0 \\
(\mathrm{DON})\end{array}$ & $\begin{array}{c}\text { Marijani et al. } \\
{[35]}\end{array}$ \\
\hline Abalone feeds & $\begin{array}{l}\text { South } \\
\text { Africa }\end{array}$ & & 0.98 & 424 & 100 & 0.259 & 100 & na & na & na & 0 & Laubscher [63] \\
\hline Tilapia feeds & Mexico & 30 & $<\mathrm{LOD}$ & 2587 & na & na & na & na & na & na & 0 & $\begin{array}{c}\text { Rodriguez- } \\
\text { Cervantes et al. } \\
{[42]}\end{array}$ \\
\hline Rainbow trout & Argentina & 28 & $2.82^{* * *}$ & $<\mathrm{LOD}$ & $230^{* *}$ & $5.26^{* *}$ & na & na & $70.08^{* *}$ & $87.97^{* *}$ & 0 & Greco et al. [38] \\
\hline Fish feeds & Iran & 86 & 68.5 & na & na & na & na & na & na & na & 17.1 & Fallah et al. [39] \\
\hline Fish feeds & Brazil & 60 & $<\mathrm{LOD}$ & 4.94 & na & $<\mathrm{LOD}$ & na & na & na & na & 0 & $\begin{array}{c}\text { Barbosa et al. } \\
{[40]}\end{array}$ \\
\hline Fish feeds & $\begin{array}{l}\text { Central } \\
\text { Europe }\end{array}$ & na & na & na & 825 & na & na & na & na & 511 & 0 & $\begin{array}{c}\text { Pietsch et al. } \\
{[64]}\end{array}$ \\
\hline Fish feeds & Egypt & 50 & 150 & na & na & na & na & na & na & na & 40 & $\begin{array}{c}\text { Hassan et al. } \\
{[44]}\end{array}$ \\
\hline Fish feeds & Brazil & 54 & $3.8^{* * *}$ & na & na & na & na & na & na & na & 0 & $\begin{array}{c}\text { Gonçalves- } \\
\text { Nunes et al. } \\
\text { [37] }\end{array}$ \\
\hline Sea bass feeds & Portugal & 87 & nd & na & na & na & na & na & na & na & 0 & $\begin{array}{c}\text { Almeida et al. } \\
{[10]}\end{array}$ \\
\hline Rainbow trout & Iran & & 67.35 & na & na & na & na & na & na & na & $\mathrm{nm}$ & $\begin{array}{c}\text { Alinezhad et al. } \\
\text { [43] }\end{array}$ \\
\hline Fish feeds & Kenya & 81 & 39.7 & na & na & na & na & na & na & na & 13.5 & $\begin{array}{c}\text { Mwihia et al. } \\
\text { [65] }\end{array}$ \\
\hline
\end{tabular}

${ }^{*}$ Maximum level of mycotoxin content in positive samples; ${ }^{* *}$ median of positive samples excluding results of estimated concentrations; ${ }^{* * *}$ mean level of mycotoxin content in positive samples; ${ }^{+}$percentage of samples that are above the permissible limit (PL) of AFs, FBs, and DON in feeds recommended by FDA [66] and EU [67]; nd, not detected; na, not analyzed in the study; nm, not mentioned in the study.

absence of aflatoxin in imported feed samples [35]. In the same study, fish feed samples from Kenya were found to be highly contaminated with aflatoxin at concentrations ranging from $<2-806.9 \mu \mathrm{g} \cdot \mathrm{kg}^{-1}$, followed by those from Tanzania $\left(<2-377.9 \mu \mathrm{g} \cdot \mathrm{kg}^{-1}\right)$, Uganda $\left(<2-28.0 \mu \mathrm{g} \cdot \mathrm{kg}^{-1}\right)$, and Rwanda $\left(<2-4.8 \mu \mathrm{g} \cdot \mathrm{kg}^{-1}\right)$. In another study from Kenya, eighty-four percent of fish feed samples were tested positive for aflatoxins, ranging from 1.8 to $39.7 \mu \mathrm{g} \cdot \mathrm{kg}^{-1}$ [65]. Other studies from tropical countries, such as Brazil [39], Iran [40], and Egypt [44], reported that fish feeds were contaminated by aflatoxin at a concentration ranging from $1.83-67.35 \mu \mathrm{g} \cdot \mathrm{kg}^{-1}$, $0.46-68.5 \mu \mathrm{g} \cdot \mathrm{kg}^{-1}$, and $52.5-150 \mu \mathrm{g} \cdot \mathrm{kg}^{-1}$, respectively. In another study from Egypt, around $42.86 \%$ of fish feed were contaminated with aflatoxins at a value higher than the permissible limit of $20 \mu \mathrm{g} \cdot \mathrm{kg}^{-1}$ [69].

Alinezhad et al. [43] observed that pellets of rainbow trout feed and feed ingredients from Iran were contaminated with aflatoxins in the range of 1.83 to $67.35 \mu \mathrm{g} \cdot \mathrm{kg}^{-1}$. Altug and Beklevik [70] reported aflatoxin contamination in 56\% of commercial fish feeds in Turkey is at levels of over $21 \mu \mathrm{g} \cdot \mathrm{kg}^{-1}$. Hassan et al. [44] studied the mycological quality of fish feed from Egypt and detected aflatoxin at significantly higher levels at mean levels of $105.2 \pm 1.3 \mu \mathrm{g} \cdot \mathrm{kg}^{-1}$ in $40 \%$ of samples.

Gonçalves-Nunes et al. [37] screened raw materials and finished fish feeds for aflatoxin contamination in Brazil.
Aflatoxin $B_{1}$ was detected in the mean level of $1.1 \mu \mathrm{g} \cdot \mathrm{kg}^{-1}$, $7.4 \mu \mathrm{g} \cdot \mathrm{kg}^{-1}$, and $3.8 \mu \mathrm{g} \cdot \mathrm{kg}^{-1}$ in maize bran, other cereal products, and finished fish feed, respectively. Another fish feed survey conducted in Brazil by Hashimoto et al. [71] detected aflatoxin at maximum contamination levels of $15.6 \mu \mathrm{g} \cdot \mathrm{kg}^{-1}$. In addition, a survey on commercial shrimp feeds conducted in the Philippines found $\mathrm{AFB}_{1}$ contamination levels up to $120 \mu \mathrm{g} \cdot \mathrm{kg}^{-1}$ [69].

Aflatoxin contamination of cottonseed cake has been a major concern worldwide as extremely high contents ranging between 200 and $300 \mathrm{mg} \cdot \mathrm{kg}^{-1}$ were reported in samples exported from the USA to the European markets [72]. In a survey done by Rodriguez et al. [73] on contamination of aflatoxins in feeds and their ingredients in the Middle East and Africa, it was found out that sunflower meal has the highest contamination level in the whole survey $\left(556 \mu \mathrm{g} \cdot \mathrm{kg}^{-1}\right)$. A survey done in East Africa by Marijani et al. [35] found that cottonseed cake intended for fish feeds was contaminated by aflatoxin with a maximum concentration of $377.9 \mu \mathrm{g} \cdot \mathrm{kg}^{-1}$, while soybeans were not contaminated. Sunflower seed cake was the only ingredient that contained the highest $\mathrm{AFB}_{1}$ concentration of $806.9 \mu \mathrm{g} \cdot \mathrm{kg}^{-1}$ when compared to maize bran, soybeans, cottonseed cake, and rice bran [35]. In another survey from Tanzania conducted by Mmongoyo et al. [74], sunflower seed cake was contaminated with aflatoxin with a maximum concentration of 
$662.7 \mu \mathrm{g} \cdot \mathrm{kg}^{-1}$ recorded. Interventions to control aflatoxin contamination along the oilseed product value chain should be implemented to enhance feed safety in African countries.

Looking at the data in Table 2, it can be confirmed that the occurrence of aflatoxin is very high from fish feeds from Africa. This is worrying as the high incidences of aflatoxicosis in human were also reported in Africa [75]. During human aflatoxicosis outbreaks in 2005 and 2006, maize were heavily contaminated with aflatoxin with maximum levels of 48,000 and 24,000 $\mu \mathrm{g} \cdot \mathrm{kg}^{-1}$, respectively [75] Daniel et al. [75] concluded that drought and famines followed by unseasonable rains during harvest and improper storage of homegrown maize in moist conditions were the reasons behind the high incidence of aflatoxicosis.

Maize intended for fish feeds was contaminated by $\mathrm{AFB}_{1}$ at a maximum concentration of $135 \mu \mathrm{g} \cdot \mathrm{kg}^{-1}$ [35]. Similar results were also reported by Reddy and Salleh [76], who found out that $22.5 \%$ of samples of maize had $\mathrm{AFB}_{1}$ contamination ranging from 20.6 to $135 \mu \mathrm{g} \cdot \mathrm{kg}^{-1}$. The poorest quality maize is used for animal feeding, which makes animals more at risk to aflatoxicosis [45].

Rice is another important staple food in Africa and Asia and its bran is widely used for animal feeding [77]. Rice bran intended for fish feed from East Africa were not contaminated by aflatoxin [35]. In another study from Iran, rice bran was contaminated by aflatoxin with the mean concentration of $18 \mu \mathrm{g} \cdot \mathrm{kg}^{-1}$ [78]. Wheat does not grow well in tropical climates; however, its bran is widely used as a component of animal and fish feeds $[28,79]$. Another cereal which is used in fish feed as an ingredient is sorghum. The incidence of aflatoxin in sorghum and millet from northern Nigeria was investigated by Apen Daneil et al. [80], and they found out that $28.6 \%$ sorghum $\left(0.96-21.74 \mu \mathrm{g} \cdot \mathrm{kg}^{-1}\right)$ and millet grain $\left(105-14.96 \mu \mathrm{g} \cdot \mathrm{kg}^{-1}\right)$ were contaminated with aflatoxin. Out of 52 ingredients intended for fish feed from East Africa, sorghum and wheat bran were detected at a very low concentration of less than $3 \mu \mathrm{g} \cdot \mathrm{kg}^{-1}[35,81]$. Another study from Brazil reported that out of 140 sorghum collected, only $12.8 \%$ were contaminated by aflatoxin [82]. Shetty and Bhat [83] found out that $20 \%$ of normal sorghum and $89 \%$ of normal maize samples also contained aflatoxin $B_{1}$. Bandyopadhyay et al. [84] suggested that if the primary cereal is sorghum instead of maize, then the risk of aflatoxin-related problems is reduced by 4 -fold. Low level of aflatoxin contamination in wheat bran, sorghum, and soya bean suggests that they are likely to be useful in the formulation of fish feeds with aflatoxin below levels that could elicit any adverse complications on fish health.

4.2. Occurrence of Fusarium Mycotoxins. There are several reports on the contamination of cereal grains and animal feed with Fusarium mycotoxins worldwide [17, 79]. The most important among them are the trichothecenes, ZEN, and the fumonisins [85]. The trichothecenes are subdivided into four basic groups, with types $\mathrm{A}$ and $\mathrm{B}$ being the most important. Type A trichothecenes include T-2 toxin, HT-2 toxin, neosolaniol, and diacetoxyscirpenol (DAS) [85]. Type $\mathrm{B}$ trichothecenes include DON also known as vomitoxin, nivalenol (NIV), and fusarenon-X. Fumonisins, particularly $\mathrm{FB}_{1}$, are found in maize grain which is a major component of feeds for warm water fish [86]. Contamination of fumonisin in cereals is dependent on the geographical region, season, and conditions under which the particular cereal is grown, harvested, and stored [45]. The prevalence of fumonisin has been reported to be $100 \%$ or close to it in all surveillance studies on maize from different parts of Africa [13]. Several studies have shown that maize bran which is mainly used for animal/fish feed has been contaminated with FBs [21, 79]. Fumonisin was detected at the concentration of $1 \mathrm{mg} \cdot \mathrm{kg}^{-1}$ on the maize bran used for animal feed from Tanzania [87]. The prevalence of $F$. verticillioides and production of $\mathrm{FB}_{1}$ in cereal grains and oilseeds in Zimbabwe was established by Gamanya [88]. While the authors did not find Fusarium and $\mathrm{FB}_{1}$ contamination in sunflower and soybean samples tested, high incidences were recorded for maize followed by wheat and sorghum [88]. Maize bran and soybeans from East Africa used for fish feeds contained a maximum of up to $3970.1 \mu \mathrm{g} \cdot \mathrm{kg}^{-1}$ and $1402.3 \mu \mathrm{g} \cdot \mathrm{kg}^{-1}$ of $\mathrm{FB}_{1}$, respectively, while cottonseed cake, sunflower seed cake, and rice bran were not contaminated with $\mathrm{FB}_{1}$ [35]. This suggests that maize is more susceptible to FBs when compared to other feed ingredients. In the same study, they found out that fish feeds processed at the farm level contained a maximum FBs concentration of $2834.6 \mu \mathrm{g} \cdot \mathrm{kg}^{-1}$ [35], and samples tested were below the regulatory limits of $5000 \mu \mathrm{g} \cdot \mathrm{kg}^{-1}$ recommended by EU [67].

DON is the most often occurring trichothecene and is prevalent in crops used for food and feed production, generally found in various cereal crops such as wheat, barley, oats, rye, rice, and maize [85]. Natural occurrence of DON in cereals is certainly prevalent, and surveys from South America, Canada, China, and many countries of Europe have shown contamination levels in excess of $50 \%$ in oats, barley, and wheat with mean concentrations as high as $9 \mathrm{mg} \cdot \mathrm{kg}^{-1}$ in barley [46]. In a survey carried out between 2004 and 2007, DON was the predominant mycotoxin with highest levels detected in wheat bran [89]. Few studies have been carried out on the contamination of DON in finished fish feeds [86]. A survey done in Central Europe has shown that more than $80 \%$ of the samples from commercial fish feed were contaminated with DON with a mean concentration of $289 \mu \mathrm{g} \cdot \mathrm{kg}^{-1}$ recorded [64]. Fish feed processed at farm level were contaminated with the mean DON concentration of $755 \mu \mathrm{g} \cdot \mathrm{kg}^{-1}$ while among the ingredients, maize bran was highly contaminated with $984 \mu \mathrm{g} \cdot \mathrm{kg}^{-1}$ [35]. Another study from Nigeria found out that fish feeds were contaminated with a mean DON concentration of $85.9 \mu \mathrm{g} \cdot \mathrm{kg}^{-1}$ [90]. All fish feeds from these studies were below the regulatory limits of $5000 \mu \mathrm{g} \cdot \mathrm{kg}^{-1}$ recommended by EU [67]. Sixty-eight samples of shrimp and fish feed from Asia and Europe were contaminated with DON at a mean concentration of $162 \mu \mathrm{g} \cdot \mathrm{kg}^{-1}$ and maximum level of $413 \mu \mathrm{g} \cdot \mathrm{kg}^{-1}$ [91].

Zearalenone, a toxic metabolite of Fusarium fungi is commonly found as contaminant in maize, and also it may occur in oats, barley, wheat, and sorghum [92]. However, the production of ZEN is favored by high humidity and low temperature conditions [93]. It may co-occur with DON in 
grains such as wheat, barley, oats, and maize and FBs in maize [92]. ZEN was found in fish feed from Asia with average concentrations of $76.2 \mu \mathrm{g} \cdot \mathrm{kg}^{-1}$ [28]. Other studies from Europe reported that fish feeds were contaminated with ZEN with a maximum concentration of $511 \mu \mathrm{g} \cdot \mathrm{kg}^{-1}$ [64]. However, the ZEN values found in these studies do not exceed the values $\left(5000 \mu \mathrm{g} \cdot \mathrm{kg}^{-1}\right)$ currently recommended by the European Commission in animal feeds [67]. DON and ZEN in unprocessed cereals and soybean were detected at the mean concentrations of $1,461 \pm 2,265 \mu \mathrm{g} \cdot \mathrm{kg}^{-1}$ and $656 \pm 853 \mu \mathrm{g} \cdot \mathrm{kg}^{-1}$, respectively, in samples collected in 2014, while in 2015 these means were $2,687 \pm 2,731 \mu \mathrm{g} \cdot \mathrm{kg}^{-1}$ and $1,140 \pm 1,630 \mu \mathrm{g} \cdot \mathrm{kg}^{-1}$, respectively [94]. The authors suggested that higher contamination determined during 2015 could be explained by high to extreme humidity evidenced in the period of cereals' growth and harvesting. The occurrence of DON and FBs in fish feeds, even at low levels, may be of concern, since it can cause growth retardation and immunotoxic effects in fish [95]. These results suggest that ZEN contamination may pose little health risk (if any) to the consumers of the fish [96].

4.3. Other Mycotoxins. Other mycotoxins like OTA, NIV, DAS, $\mathrm{T}-2$ toxin, alternariol (AOH), and ROQ-C have been reported to occur in fish feeds and ingredients intended for fish feed formulation [35]. Cottonseed cake for fish feed formulation was the only ingredient contaminated by OTA with a maximum concentration of $24.2 \mu \mathrm{g} \cdot \mathrm{kg}^{-1}$ [35]. Nivalenol was detected in fish feeds processed at farm level with a maximum concentration of $732.5 \mu \mathrm{g} \cdot \mathrm{kg}^{-1}$, while no ingredients intended for fish feeding was contaminated by NIV. Other mycotoxins like DAS, T-2, and ROQ-C were detected in fish feeds and their ingredients but at very low concentrations [35].

Also, an immunosuppressive mycotoxin, gliotoxin, was detected in oilseed cakes at levels up to $45 \mu \mathrm{g} \cdot \mathrm{kg}^{-1}$, which was associated with the presence of toxigenic isolates of $A$. fumigatus [97].

\section{Effects of Mycotoxin on Fish Health}

The toxic effects of mycotoxins are not only depended on the dose in feeds but as well as on the duration of toxin exposure, species, as well as the sex and age of the animal [94].

Among the mycotoxins, $\mathrm{AFB}_{1}$ is the most studied in fish, possibly because of its natural occurrence being most widely found in tropical countries and that it is a known human carcinogen and most potent hepatotoxin [98]. These studies on toxicity effect of $\mathrm{AFB}_{1}$ on farmed aquatic species include rainbow trout, [23, 99, 100]; Nile tilapia, [14, 19, 101-104]; channel catfish, [22, 105]; rohu, [106, 107]; sea bass, [98]; gibel carp, [18]; beluga, [108]; and abalone [63].

Considering the results of the studies in Table 3 , the biological effects of $\mathrm{AFB}_{1}$ in these aquatic species depend on the toxin's concentration in feed and species. Channel catfish, Ictalurus punctatus, appears to be one of the most resistant among fish species when exposed to $\mathrm{AFB}_{1}$, while rainbow trout is the most sensitive to $\mathrm{AFB}_{1}$, and exposing them at concentrations as low as $0.4 \mu \mathrm{g} \mathrm{AFB}_{1} \mathrm{~kg}^{-1}$ may cause a $14 \%$ chance of developing tumors [22, 99]. Previously, there are no studies on hepatocellular carcinomas in channel fish caused by $\mathrm{AFB}_{1}$, but there are reports that dosing them with higher concentrations of $\mathrm{AFB}_{1}$ resulted in decreased growth rate and moderate internal lesions [22]. European sea bass is also sensitive to $\mathrm{AFB}_{1}$; El-Sayed and Khalil [98] found that exposing them for 4 days with median lethal concentration (LC50) of $180 \mu \mathrm{g} \mathrm{kg}^{-1} \mathrm{AFB}_{1}$ causes aflatoxicosis. Other studies on fish have shown reduced growth rates particularly on Nile tilapia and channel catfish-fed diets containing 1880 and $10000 \mu \mathrm{g} \mathrm{AFB}_{1} \mathrm{~kg}^{-1}$ feed, respectively $[14,17,22]$. The mortality rate of $17 \%$ was reported in Nile tilapia fed diets containing $2000 \mu \mathrm{g} \mathrm{AFB}_{1} \mathrm{~kg}^{-1}$ [101]. Aflatoxin is also known to affect eye opacity resulting in cataract and blindness, yellowing of the body surface, wounds on the body surface, fin and tail rot, abnormal swimming, feeble and stationary movements, and reduced appetite in tilapiafed aflatoxin-contaminated diet [19].

Aflatoxin has been reported to disrupt the reproductive system in both male and female animals; however, very few studies had been reported in aquatic animals [116]. The few existing studies show a significant decrease in ovary weight, fecundity, and egg size of gibel carp fed on $\mathrm{AFB}_{1}$-treated ration [18]. In Nile tilapia, a negative effect on gonadosomatic index, fecundity, sperm count, sperm activity, and serum estradiol-17 $\beta$ concentrations was observed after feeding them with 1 and $3 \mathrm{mg} \cdot \mathrm{kg}^{-1} \mathrm{AFB}_{1}$ contaminated for 3 months [117].

The contamination values of AFs found in fish feeds and their ingredients from Africa were high (Table 2) and, as shown in Table 3, can negatively affect farmed fish, thus leading to economic loss to fish farmers.

Fusarium mycotoxins are able to induce both acute and chronic toxic effects. Previous studies have shown that these effects depend on the dose, duration of exposure, and fish species that are exposed (Table 4). Rainbow trout are sensitive to DON when exposed at low dose, while channel catfish are much less responsive (Table 4). Hooft et al. [100] reported that feeding rainbow trout with low, graded levels of DON ranging from $3.0 \times 10^{-4}$ to $2.6 \times 10^{-3} \mathrm{mg} \cdot \mathrm{kg}^{-1}$ from naturally contaminated maize resulted in highly significant decrease in growth, feed intake, feed efficiency, and protein and energy utilization, whereas channel catfish fed of diets containing up to $10 \mathrm{mg} \cdot \mathrm{kg}^{-1} \mathrm{DON}$ from either a purified source or naturally contaminated wheat had no effect on the feed consumption, growth, hematocrit values, or liver weight [119]. Also, the rainbow trout liver is sensitive to $\mathrm{FB}_{1}$ because it induces changes in sphingolipid metabolism [131] and is a cancer promoter in this species [123]. Growth performance of Nile tilapia fingerlings was negatively affected when fed with both moniliformin (MON) and $\mathrm{FB}_{1}$ at 70 and $40 \mathrm{mg} \cdot \mathrm{kg}^{-}$ ${ }^{1}$, respectively. However, when compared to channel catfish, Nile tilapia appears to be more resistant to these two mycotoxins as no mortality and histopathological lesions have been reported [102].

Reduction in growth, feed efficiency, and feed intake in fish fed with DON-contaminated diet was reported by Tola et al. [95], Hooft et al. [100], and Döll et al. [118]; however, 
TABle 3: Toxic effects of aflatoxins, ochratoxin A, and sterigmatocystin in different fish species.

\begin{tabular}{|c|c|c|c|c|c|c|}
\hline Mycotoxin & Species & Exposure dose & Administration & $\begin{array}{c}\text { Duration of } \\
\text { exposure } \\
\text { (weeks) }\end{array}$ & Toxicity effect & References \\
\hline \multirow{12}{*}{ Aflatoxin } & $\begin{array}{l}\text { Nile tilapia } \\
\text { (Oreochromis } \\
\text { niloticus) }\end{array}$ & $100 \mu \mathrm{g} \mathrm{AFB}_{1} / \mathrm{kg}$ & Feed: oral & 10 & Reduced the growth & $\begin{array}{c}\text { El-Banna et al. } \\
{[101]}\end{array}$ \\
\hline & Nile tilapia & $200 \mu \mathrm{g} \quad \mathrm{AFB}_{1} / \mathrm{kg}$ & Feed: oral & 10 & Mortality (16.7\%) & $\begin{array}{c}\text { El-Banna et al. } \\
{[101]}\end{array}$ \\
\hline & Nile tilapia & $\begin{array}{c}5-38.62 \mu \mathrm{g} \mathrm{AFB}_{1} / \\
\mathrm{kg}\end{array}$ & Feed: oral & 10 & $\begin{array}{c}\text { Survival rate reduced by up } \\
\text { to } 67 \%\end{array}$ & $\begin{array}{l}\text { Cagauan and } \\
\text { Tayaban [19] }\end{array}$ \\
\hline & Nile tilapia & $29 \mu \mathrm{g} \mathrm{AFB}_{1} / \mathrm{kg}$ & Feed: oral & 10 & $\begin{array}{l}\text { Yellowing of the body } \\
\text { surface }\end{array}$ & $\begin{array}{l}\text { Cagauan and } \\
\text { Tayaban [19] }\end{array}$ \\
\hline & Tilapia & $200 \mathrm{ppb} \mathrm{AFB}_{1} / \mathrm{kg}$ & Feed: oral & 10 & $\begin{array}{l}\text { Total erythrocyte count, } \\
\text { total leucocyte count, and } \\
\text { hemoglobin count } \\
\text { decreased; weight gain } \\
\text { lowest and reduction in the } \\
\text { rate survival rate }\end{array}$ & $\begin{array}{l}\text { Selim et al. } \\
\text { [104] }\end{array}$ \\
\hline & Tilapia & $\begin{array}{l}793 \text { and } 1641 \mu \mathrm{g} \\
\mathrm{AFB}_{1} / \mathrm{kg}\end{array}$ & Feed: oral & 5 & $\begin{array}{c}\text { Yellowing of the body } \\
\text { surface }\end{array}$ & $\begin{array}{l}\text { Deng et al. } \\
\text { [103] }\end{array}$ \\
\hline & Tilapia & $\begin{array}{l}793 \text { and } 1641 \mu \mathrm{g} \\
\mathrm{AFB}_{1} / \mathrm{kg}\end{array}$ & Feed-oral & 15 & Darkening of body surface & $\begin{array}{l}\text { Deng et al. } \\
\text { [103] }\end{array}$ \\
\hline & Tilapia & $2.5 \mathrm{mg} \mathrm{AFB}_{1} / \mathrm{kg}$ & Feed: oral & & $\begin{array}{l}\text { Affect the hematocrit and } \\
\text { growth performance }\end{array}$ & $\begin{array}{l}\text { Tuan et al. } \\
\text { [109] }\end{array}$ \\
\hline & Tilapia & $2.5 \mathrm{mg} \mathrm{AFB}_{1} / \mathrm{kg}$ & Feed: oral & 20 & Abnormal behavior & $\begin{array}{l}\text { Deng et al. } \\
\text { [103] }\end{array}$ \\
\hline & Tilapia & $245 \mu \mathrm{g} \mathrm{AFB}_{1} / \mathrm{kg}$ & Feed: oral & 20 & $\begin{array}{c}\text { Feed efficiency rate } \\
\text { decreased }\end{array}$ & $\begin{array}{l}\text { Deng et al. } \\
\text { [103] }\end{array}$ \\
\hline & & $\begin{array}{c}245,638,793 \text { and } \\
1641 \mu \mathrm{g} \mathrm{AFB}_{1} / \mathrm{kg}\end{array}$ & Feed: oral & 20 & Weight gain lowest & $\begin{array}{l}\text { Deng et al. } \\
\text { [103] }\end{array}$ \\
\hline & $\begin{array}{l}\text { Channel catfish } \\
\text { (Ictalurus punctatus) }\end{array}$ & $10000 \mu \mathrm{g} \mathrm{AFB}{ }_{1} / \mathrm{kg}$ & Feed: oral & 10 & $\begin{array}{c}\text { Decreased leukocyte count, } \\
\text { increased haematopoietic } \\
\text { activity of blood-forming } \\
\text { tissues }\end{array}$ & $\begin{array}{l}\text { Jantaroai and } \\
\text { Lovell [22] }\end{array}$ \\
\hline \multirow{5}{*}{ Aflatoxin } & Rohu (Labeo rohita) & $\begin{array}{c}2.50 \text { and } \\
5.00 \mathrm{mg} \cdot \mathrm{kg}^{-1}\end{array}$ & $\begin{array}{l}\text { Intraperitoneal } \\
\text { (i.p.) }\end{array}$ & 10 & $\begin{array}{c}\text { Reduction in production of } \\
\text { oxygen radicals by } \\
\text { neutrophils }\end{array}$ & $\begin{array}{c}\text { Sahoo and } \\
\text { Mukherjee } \\
{[110]}\end{array}$ \\
\hline & Rohu & $\begin{array}{l}1.25 ; 2.50 \text { and } \\
5.00 \mathrm{mg} \cdot \mathrm{kg}^{-1}\end{array}$ & $\begin{array}{l}\text { Intraperitoneal } \\
\text { (i.p.) }\end{array}$ & 10 & $\begin{array}{l}\text { Reduction of total protein } \\
\text { and globulin levels }\end{array}$ & $\begin{array}{l}\text { Sahoo and } \\
\text { Mukherjee } \\
{[110]}\end{array}$ \\
\hline & $\begin{array}{l}\text { Gibel carp (Carassius } \\
\text { auratus gibelio) }\end{array}$ & $\begin{array}{l}\text { 20, and } 2000 \mu \mathrm{g} \\
\mathrm{AFB}_{1} \mathrm{~kg}^{-1}\end{array}$ & Feed: oral & 24 & $\begin{array}{l}\text { Total erythrocyte count, } \\
\text { total leucocyte count, } \\
\text { hemoglobin count, and } \\
\text { nitroblue tetrazolium } \\
\text { decreased } \\
\text { Gonadosomatic index } \\
\text { (GSI), absolute brood } \\
\text { amount (AF), relative brood } \\
\text { amount (RF), and oocyte } \\
\text { diameter were significantly } \\
\text { lower }\end{array}$ & $\begin{array}{l}\text { Huang et al. } \\
{[18]}\end{array}$ \\
\hline & $\begin{array}{l}\text { Juvenile rainbow } \\
\text { trout }\end{array}$ & $1190 \mu \mathrm{g} \cdot \mathrm{kg}^{-1}$ & Feed: oral & 3 & Mortality & $\begin{array}{c}\text { Nomura et al. } \\
\text { [99] }\end{array}$ \\
\hline & $\begin{array}{l}\text { Sea bass } \\
\text { (Dicentrarchus } \\
\text { labrax L.) }\end{array}$ & $0.018 \mathrm{mg} \cdot \mathrm{kg}^{-1}$ & Feed: oral & 4 days & $\begin{array}{l}\text { Loss of equilibrium, rapid } \\
\text { opercular movement, and } \\
\text { hemorrhages of the dorsal } \\
\text { skin surface } \\
\text { *ALT, AST, and ALP } \\
\text { enzymes increased; total } \\
\text { protein; Albumin; and } \\
\text { Globulin increased }\end{array}$ & $\begin{array}{l}\text { El-Sayed and } \\
\text { Khali [98] }\end{array}$ \\
\hline
\end{tabular}


TABle 3: Continued.

\begin{tabular}{|c|c|c|c|c|c|c|}
\hline Mycotoxin & Species & Exposure dose & Administration & $\begin{array}{c}\text { Duration of } \\
\text { exposure } \\
\text { (weeks) }\end{array}$ & Toxicity effect & References \\
\hline \multirow{3}{*}{ OTA } & \multirow{3}{*}{ Channel catfish } & $\begin{array}{l}1.0,2.0,4.0, \text { or } \\
8.0 \mathrm{mg} \cdot \mathrm{kg}^{-1}\end{array}$ & Feed: oral & 8 & $\begin{array}{l}\text { Reductions in body weight } \\
\text { gain }\end{array}$ & $\begin{array}{l}\text { Manning et al. } \\
{[111]}\end{array}$ \\
\hline & & 4.0 , or $8.0 \mathrm{mg} \cdot \mathrm{kg}^{-1}$ & Feed: oral & 8 & $\begin{array}{l}\text { Feed conversion ratio was } \\
\text { significantly poorer }\end{array}$ & $\begin{array}{l}\text { Manning et al. } \\
{[111]}\end{array}$ \\
\hline & & $8.0 \mathrm{mg} \cdot \mathrm{kg}^{-1}$ & Feed: oral & 8 & $\begin{array}{c}\text { Hematocrit was significantly } \\
\text { lower }\end{array}$ & $\begin{array}{c}\text { Manning et al. } \\
{[111]}\end{array}$ \\
\hline OTA & $\begin{array}{l}\text { Juvenile common } \\
\text { carp }\end{array}$ & $4.0 \mathrm{mg} \cdot \mathrm{kg}^{-1}$ & Feed: oral & 6 & Mortality (80.49\%) & $\begin{array}{l}\text { Manning et al. } \\
{[112]}\end{array}$ \\
\hline OTA & $\begin{array}{l}\text { Black tiger shrimp } \\
\text { (Penaeus monodon) }\end{array}$ & $1000 \mu \mathrm{g} \cdot \mathrm{kg}^{-1}$ & Feed: oral & 8 & $\begin{array}{c}\text { No negative impact in } \\
\text { shrimp }\end{array}$ & $\begin{array}{l}\text { Supamattaya } \\
\text { et al. [113] }\end{array}$ \\
\hline Stg & Nile tilapia & $\begin{array}{l}5,10 \text { and } \\
50 \mu \mathrm{g} \cdot \mathrm{ml}^{-1}\end{array}$ & Intragastric & 4 & $\begin{array}{l}\text { Clastogenic, decrease of } \\
\text { body weight, and the } \\
\text { increase in frequencies of } \\
\text { micronucleated red blood } \\
\text { cells (MN RBC) and } \\
\text { chromosomal aberrations in } \\
\text { the kidney }\end{array}$ & $\begin{array}{c}\text { Abdel- } \\
\text { Wahhab et al. } \\
{[114]}\end{array}$ \\
\hline Stg & Nile tilapia & $1.6 \mu \mathrm{g} \cdot \mathrm{kg}^{-1} \mathrm{bwt}$ & Corn oil: oral & 4 & $\begin{array}{l}\text { Genotoxic and } \\
\text { toxicopathological effects }\end{array}$ & $\begin{array}{c}\text { Mahrous et al. } \\
\text { [115] }\end{array}$ \\
\hline
\end{tabular}

*ALT: alanine aminotransferase; ALP: alkaline phosphatase; AST: aspartate transaminase.

Table 4: Toxic effects of Fusarium mycotoxins in different species of fish.

\begin{tabular}{|c|c|c|c|c|c|c|}
\hline Mycotoxin & Species & Exposure dose & Administration & $\begin{array}{l}\text { Duration of } \\
\text { exposure } \\
\text { (weeks) }\end{array}$ & Toxicity effect & References \\
\hline \multirow{3}{*}{ DON } & $\begin{array}{c}\text { Rainbow trout } \\
\text { Oncorhynchus mykiss }\end{array}$ & $2.6 \mathrm{mg} \cdot \mathrm{kg}^{-1}$ & Feed: oral & 8 & $\begin{array}{l}\text { Decrease in growth, feed } \\
\text { intake, feed efficiency, and } \\
\text { protein and energy } \\
\text { utilization. }\end{array}$ & $\begin{array}{l}\text { Hooft et al. } \\
\text { [100] }\end{array}$ \\
\hline & $\begin{array}{c}\text { Atlantic salmon Salmo } \\
\text { salar } \mathrm{L} .\end{array}$ & $3.7 \times 10^{-3} \mathrm{mg} \cdot \mathrm{kg}^{-1}$ & & 8 & $\begin{array}{l}\text { Reduction in feed intake } \\
\text { and decrease in specific } \\
\text { growth rate }\end{array}$ & $\begin{array}{l}\text { Döll et al. } \\
\text { [118] }\end{array}$ \\
\hline & $\begin{array}{c}\text { Channel catfish Ictalurus } \\
\text { punctatus }\end{array}$ & $5.0-10.0 \mathrm{mg} \cdot \mathrm{kg}^{-1}$ & Feed: oral & 8 & Mortality & $\begin{array}{l}\text { Manning et al. } \\
{[119]}\end{array}$ \\
\hline \multirow{6}{*}{$\mathrm{T}-2$ toxin } & \multirow{2}{*}{ Juvenile channel catfish } & $\begin{array}{l}1.25,2.5, \text { and } \\
5.0 \mathrm{mg} \cdot \mathrm{kg}^{-1}\end{array}$ & Feed: oral & 8 & $\begin{array}{l}\text { Reductions in growth and } \\
\text { hematocrit values were } \\
\text { adversely affected }\end{array}$ & $\begin{array}{l}\text { Manning et al. } \\
{[120]}\end{array}$ \\
\hline & & $5.0 \mathrm{mg} \cdot \mathrm{kg}^{-1}$ & Feed: oral & 8 & $\begin{array}{c}\text { Histopathological } \\
\text { anomalies of stomach, } \\
\text { head, and trunk kidneys }\end{array}$ & $\begin{array}{l}\text { Manning et al. } \\
{[120]}\end{array}$ \\
\hline & \multirow[t]{2}{*}{ Juvenile common carp } & 1.0 or $2.0 \mathrm{mg} \cdot \mathrm{kg}^{-1}$ & Feed: oral & 6 & Mortality & $\begin{array}{l}\text { Manning et al. } \\
{[112]}\end{array}$ \\
\hline & & $\begin{array}{l}1.2,2.4,4.8 \text {, and } \\
12.2 \mathrm{mg} \cdot \mathrm{kg}^{-1}\end{array}$ & Feed: oral & 3 & $\begin{array}{c}\text { Decrease in growth and } \\
\text { survival rate }\end{array}$ & $\begin{array}{l}\text { Deng et al. } \\
\text { [103] }\end{array}$ \\
\hline & \multirow[t]{2}{*}{$\begin{array}{l}\text { Pacific white shrimp } \\
\text { Litopenaeus vannamei }\end{array}$} & $\begin{array}{c}2.4 \text { and } \\
4.8 \mathrm{mg} \cdot \mathrm{kg}^{-1}\end{array}$ & Feed: oral & 3 & $\begin{array}{l}\text { Antioxidant enzymes, } \\
\text { superoxide dismutase } \\
\text { (SOD) and glutathione } \\
\text { peroxidase (GPx), total } \\
\text { antioxidant capacity (T- } \\
\text { AOC), and also glutathione } \\
\text { (GSH) content increased }\end{array}$ & $\begin{array}{l}\text { Deng et al. } \\
\text { [103] }\end{array}$ \\
\hline & & $12.2 \mathrm{mg} \cdot \mathrm{kg}^{-1}$ & Feed: oral & 3 & $\begin{array}{l}\text { SOD and GPx, T-AOC, and } \\
\text { GSH content decreased, } \\
\text { cell autophagy }\end{array}$ & $\begin{array}{l}\text { Deng et al. } \\
\text { [103] }\end{array}$ \\
\hline
\end{tabular}


TABLE 4: Continued.

\begin{tabular}{|c|c|c|c|c|c|c|}
\hline Mycotoxin & Species & Exposure dose & Administration & $\begin{array}{l}\text { Duration of } \\
\text { exposure } \\
\text { (weeks) }\end{array}$ & Toxicity effect & References \\
\hline \multirow{4}{*}{ MON } & Channel catfish & $\begin{array}{l}20,40,60 \text {, and } \\
120 \mathrm{mg} \cdot \mathrm{kg}^{-1}\end{array}$ & Feed: oral & 10 & Reductions in growth, & $\begin{array}{l}\text { Yildirim et al. } \\
\text { [121] }\end{array}$ \\
\hline & Channel catfish & $60 \mathrm{mg} \cdot \mathrm{kg}^{-1}$ & Feed: oral & 10 & $\begin{array}{l}\text { Low hematocrit level and } \\
\text { high serum pyruvate level }\end{array}$ & $\begin{array}{c}\text { Yildirim et al. } \\
{[121]}\end{array}$ \\
\hline & Nile tilapia & $\begin{array}{c}60 \text { and } \\
150 \mathrm{mg} \cdot \mathrm{kg}^{-1}\end{array}$ & Feed: oral & 8 & $\begin{array}{l}\text { Reductions in growth and } \\
\text { high serum pyruvate levels }\end{array}$ & $\begin{array}{l}\text { Tuan et al. } \\
\text { [122] }\end{array}$ \\
\hline & Nile tilapia & $150 \mathrm{mg} \cdot \mathrm{kg}^{-1}$ & Feed: oral & 8 & $\begin{array}{l}\text { Hematocrit was } \\
\text { significantly low }\end{array}$ & $\begin{array}{l}\text { Tuan et al. } \\
\text { [122] }\end{array}$ \\
\hline \multirow{8}{*}{$\mathrm{FB}_{1}$} & Channel catfish & $\begin{array}{l}80,320, \text { or } \\
720 \mathrm{mg} \cdot \mathrm{kg}^{-1}\end{array}$ & Feed: oral & 14 & $\begin{array}{l}\text { Reductions in growth, } \\
\text { lower hematocrit and red } \\
\text { cell counts, and higher } \\
\text { white cell counts }\end{array}$ & $\begin{array}{l}\text { Lumlertdacha } \\
\text { et al. [105] }\end{array}$ \\
\hline & Channel catfish & $\begin{array}{l}20,80,320, \text { or } \\
720 \mathrm{mg} \cdot \mathrm{kg}^{-1}\end{array}$ & Feed: oral & 14 & $\begin{array}{l}\text { Swollen hepatocytes in the } \\
\text { liver with lipid-containing } \\
\text { vacuoles, lymphocyte } \\
\text { infiltration, and scattered } \\
\text { necrotic hepatocytes }\end{array}$ & $\begin{array}{l}\text { Lumlertdacha } \\
\text { et al. [105] }\end{array}$ \\
\hline & Rainbow trout & $23 \mathrm{mg} \cdot \mathrm{kg}^{-1}$ & Feed: oral & 42 & Cancer promoter & $\begin{array}{l}\text { Carlson et al. } \\
\text { [123] }\end{array}$ \\
\hline & Nile tilapia & $\begin{array}{c}40,70, \\
150 \mathrm{mg} \cdot \mathrm{kg}^{-1}\end{array}$ & Feed: oral & 8 & Lower mean weight gains & $\begin{array}{l}\text { Tuan et al. } \\
\text { [122] }\end{array}$ \\
\hline & Nile tilapia & $150 \mathrm{mg} \cdot \mathrm{kg}^{-1}$ & Feed: oral & 8 & $\begin{array}{l}\text { Haematocrit was decreased } \\
\text { and ratio between free } \\
\text { sphinganine and free } \\
\text { sphingosine (SA/SO) in the } \\
\text { liver increased }\end{array}$ & $\begin{array}{l}\text { Tuan et al. } \\
\text { [122] }\end{array}$ \\
\hline & $\begin{array}{c}\text { Common carp Cyprinus } \\
\text { carpio }\end{array}$ & $\begin{array}{c}100 \text { and } \\
10 \mathrm{mg} \cdot \mathrm{kg}^{-1}\end{array}$ & Feed: oral & 6 & $\begin{array}{l}\text { Blood vessels, liver, } \\
\text { exocrine and endocrine } \\
\text { pancreas, excretory and } \\
\text { haematopoietic kidney, and } \\
\text { heart and brain were } \\
\text { sensitive }\end{array}$ & $\begin{array}{l}\text { Petrinec et al. } \\
{[124]}\end{array}$ \\
\hline & Common carp & $\begin{array}{c}0.5 \text { and } \\
5.0 \mathrm{mg} \cdot \mathrm{kg}^{-1}\end{array}$ & Feed: oral & 6 & $\begin{array}{l}\text { Loss of body weight and } \\
\text { alterations of } \\
\text { haematological and } \\
\text { biochemical parameters in } \\
\text { target organs }\end{array}$ & $\begin{array}{l}\text { Pepeljnjak } \\
\text { et al. [125] }\end{array}$ \\
\hline & & $5.0 \mathrm{mg} \cdot \mathrm{kg}^{-1}$ & Feed: oral & 6 & $\begin{array}{c}\text { Increase in bacterial } \\
\text { infection }\end{array}$ & $\begin{array}{l}\text { Pepeljnjak } \\
\text { et al. [125] }\end{array}$ \\
\hline \multirow{5}{*}{ ZEN } & Zebrafish Danio rerio & $\begin{array}{l}1000 \text { and } \\
3200 \mathrm{ng}^{-1} \mathrm{~L}^{-1}\end{array}$ & & 6 & $\begin{array}{l}\text { Reduced spawning } \\
\text { frequency }\end{array}$ & $\begin{array}{c}\text { Schwartz et al. } \\
{[126]}\end{array}$ \\
\hline & Zebrafish & $1000 \mathrm{ng} \cdot \mathrm{L}^{-1}$ & & 26 & $\begin{array}{l}\text { Affect growth and changed } \\
\text { relative fecundity from one } \\
\text { generation to another }\end{array}$ & $\begin{array}{c}\text { Schwartz et al. } \\
{[127]}\end{array}$ \\
\hline & $\begin{array}{l}\text { Black tiger shrimp } \\
\text { Penaeus monodon } \\
\text { Fabricius }\end{array}$ & $\begin{array}{l}500 \text { and } \\
1000 \mathrm{mg} \cdot \mathrm{kg}^{-1}\end{array}$ & Feed: oral & 10 & $\begin{array}{l}\text { Histological changes in } \\
\text { hepatopancreatic tissue }\end{array}$ & $\begin{array}{l}\text { Bundit et al. } \\
{[128]}\end{array}$ \\
\hline & Common carp & $\begin{array}{l}0.332,0.621 \text { and } \\
0.797 \mathrm{mg} \cdot \mathrm{kg}^{-1}\end{array}$ & Feed: oral & 4 & $\begin{array}{l}\text { No effect on growth but } \\
\text { effects on haematological } \\
\text { parameters }\end{array}$ & $\begin{array}{l}\text { Pietsch et al. } \\
\text { [129] }\end{array}$ \\
\hline & Juvenile rainbow trout & $1.810 \mathrm{mg} \cdot \mathrm{kg}^{-1}$ & Feed: oral & 10 & $\begin{array}{l}\text { No effects on growth and } \\
\text { may accelerate sexual } \\
\text { maturation of female fish }\end{array}$ & $\begin{array}{l}\text { Woźny et al. } \\
\text { [130] }\end{array}$ \\
\hline
\end{tabular}

there are also reports of DON not interfering in the weight gain of fish $[132,133]$.

ZEN has been implicated in reproductive disorders of farm animals [134]; however, very few studies have been done on the effect of ZEN in farmed aquatic species. In zebrafish (Danio rerio), ZEN reduced spawning frequency [126] or changed their relative fecundity from one generation to another [127]. In another study, defects in the heart 
and eye development and upward curvature of the body axis of were observed when zebrafish larvae were exposed to $500 \mu \mathrm{g} \cdot \mathrm{L}^{-1}$ or higher of ZEN [135]. By considering the few studies made in aquaculture species (Table 4), we would presume that ingestion of ZEN may affect growth performance, but it depends on species, dose, and duration of exposure, and it can result in complications in broodstocks of farmed species and monosex-cultured species.

Scarce information is available on the toxicity of OTA in aquatic species. A significant reduction in weight gain, poorer feed conversion rate, lower survival, and hematocrit was observed in channel catfish fed with OTA-contaminated diets [111]. Furthermore, moderate-to-severe histopathological lesions of the liver and posterior kidney were observed [113]. While a significant decrease in erythrocyte count (RBCs), haemoglobin content $(\mathrm{Hb})$, and haematocrit value (Hct) in Nile tilapia exposed to low OTA level $\left(400 \mu \mathrm{g} \cdot \mathrm{kg}^{-1}\right)$ was seen, in Nile tilapia exposed to $600 \mu \mathrm{g} \cdot \mathrm{kg}^{-1}$ diet mean corpuscular volume (MCV), mean corpuscular haemaglobin $(\mathrm{MCH})$, and mean corpuscular haemaglobin concentrate (MCHC) blood indices significantly reduced [136]. In addition, as shown in Table 4, OTA has a negative impact on shrimp even after feeding them with $1000 \mu \mathrm{g} \cdot \mathrm{kg}^{-1}$ contaminated diet for 8 weeks. However, increasing the dose and exposure duration might affect the shrimp negatively.

Other mycotoxins like sterigmatocystin, which is closely related to the aflatoxin as a precursor in aflatoxin biosynthesis and carcinogenic, have been studied in Nile tilapia [115]. Stg has genotoxic and toxicopathological effects in Nile tilapia, [115]. Stg also decreases body weight and increase in frequencies of micronucleated red blood cells ( $\mathrm{MN}$ RBC) and chromosomal aberrations in the kidney of Nile tilapia [114]. Studies on the effects of ROQ-C on animals and fish are limited; however, CPA has been reported to cause anorexia, diarrhea, pyrexia, dehydration, weight loss, ataxia, immobility, and extensor spasm at the time of death in several animals [33].

As shown in Tables 3 and 4, different studies highlight that mycotoxins are a serious problem to farmed aquatic species. A majority of these experiments were conducted based on chronic character, contaminated feed as the route of exposure, and several different doses. It is important to maintain standards when performing the experiments in relation to sex, as studies show that male animals are more susceptible to mycotoxin [137], divide the toxicology tests on acute, subchronic, and chronics, and also consider species, age, rearing conditions, route of exposure, and dose according to each type of mycotoxins, mainly to detect toxic effects on fish.

\section{Synergistic Effect of Mycotoxins in Fish}

Mycotoxins often occur concurrently [40]. Thes multiple mycotoxin contaminations in fish feeds are crucial as mycotoxins may toxicologically interact with each other eliciting marked synergistic and additive actions [138] especially between mycotoxins found at high concentrations. This might increase the negative impact of mycotoxins in farmed aquatic species at lower levels than when present in single contamination. There are limited data on toxic effects of mycotoxin mixtures in farmed aquatic species [123]. $\mathrm{FB}_{1}$ was not carcinogenic when rainbow trout was fed at $0,3.2,23$, or $104 \mathrm{mg} \cdot \mathrm{kg}^{-1} \mathrm{FB}_{1}$ for a total of 34 weeks. But trout-fed $\mathrm{FB}_{1}$ $\left(\geq 23 \mathrm{mg} \cdot \mathrm{kg}^{-1} \mathrm{FB}_{1}\right.$ for 42 weeks) promoted $\mathrm{AFB}_{1}$-initiated liver tumors; this result also suggests the importance of longterm contamination as a factor influencing the susceptibility of animals. He et al. [139] examined the individual and synergistic effect of $\mathrm{DON}$ and $\mathrm{AFB}_{1}$ on primary hepatocytes of common carp and inferred that the toxic effects of the combined mycotoxins were greater than the effects of single mycotoxins. McKean et al. [140] examined the synergistic effects of $\mathrm{AFB}_{1}$ and $\mathrm{T}-2$ toxin in mosquitofish (Gambusia affinis), showing a significant additive interaction in the toxic response to the combination of mycotoxins. The cooccurrence of AF and OTA presents a health risk in fish because of their synergistic and/or additive effects [141]. Critical is that these mycotoxins can potentially be carried over to human food of animal origin and may cause public health threats [141]. To the best of our knowledge, very few studies were carried out for investigating the interacting effects of multimycotoxins in farmed aquatic animals; however, considering the previous studies carried out for other animals [142-144], we could consider that mycotoxin interactions may likewise affect negatively farmed aquatic species.

\section{Conclusion}

This review shows that fish feeds and their ingredients are frequently contaminated with mycotoxigenic fungi and mycotoxins. Ingredients, especially grains and oilseeds, are the main reservoirs for mycotoxins in fish feed. Ingestion of mycotoxin-contaminated feeds can affect fish health and also contributes to the economic loss of the fish farmers. Also, attention should be taken on the possible carryover of mycotoxins from feed ingredients and finished feed to the meat of farmed aquatic animals for human consumption. Hence, it is important to ensure the control of mycotoxin contamination in fish feeds and their ingredients. Use of seed coat with the small, compact grains (wheat, rice, oat, and sorghum) and those encapsulated in hard seed coats (beans and soybeans) might reduce the contamination of mycotoxin in feeds since they are less susceptible to fungal infection and mycotoxin formation than larger grains such as maize. Since mycotoxins are also produced during storage conditions, it will be important to monitor routinely raw materials as well as finished feeds. Awareness and sensitization on proper storage facilities, duration, and condition for feeds and ingredients are recommended to farmers. Antifungal agents should be used to reduce mycotoxin contamination in feed ingredients and finished fish feeds. Further research is needed to test the synergistic effects of mycotoxins when diets are contaminated with more than one mycotoxin.

\section{Conflicts of Interest}

The authors declare that they have no conflicts of interest. 


\section{References}

[1] High Level Panel of Experts (HLPE), Sustainable Fisheries and Aquaculture for Food Security and Nutrition, Food and Agriculture Organization, Rome, Italy, 2014.

[2] S. Tveterås, F. Asche, M. F. Bellemare et al., "Fish is food-the FAO's fish price index," PLoS One, vol. 7, no. 5, Article ID e36731, 2012.

[3] Food and Agricultural Organisation (FAO), The State of World Fisheries and Aquaculture, Food and Agricultural Organisation (FAO), Rome, Italy, 2016.

[4] H. Charo-Karisa and M. Gichuri, "Overview of the fish farming enterprise productivity program," in End of Year Report Fish Farming Enterprise Productivity Program Phase I, Aquaculture Development Working Group, Nairobi, Kenya, 2010.

[5] A. Anater, L. Manyes, G. Meca et al., "Mycotoxins and their consequences in aquaculture: a review," Aquaculture, vol. 451, pp. 1-10, 2016.

[6] C. C. Alceste and D. E. Jory, "Tilapia-alternative protein sources in tilapia feed formulation," Aquaculture Magazine, vol. 26, pp. 70-75, 2000.

[7] E. Kjørsvik, A. Mangor-Jensen, and I. Holmefjord, "Egg quality in fishes," Advances in Marine Biology, vol. 26, pp. 71-113, 1990.

[8] D. M. Liti, R. M. Mugo, J. M. Munguti, and H. Waidbacher, "Growth and economic performance of Nile tilapia (Oreochromis niloticus L.) fed on three brans (maize, wheat and rice) in fertilized ponds," Aquaculture Nutrition, vol. 12, no. 3, pp. 239-245, 2006.

[9] D. Liti, L. Cherop, J. Munguti, and L. Chhorn, "Growth and economic performance of Nile tilapia (Oreochromis niloticus L.) fed on two formulated diets and two locally available feeds in fertilized ponds," Aquaculture Research, vol. 36, no. 8, pp. 746-752, 2005.

[10] I. F. Almeida, H. M. L. Martins, S. M. O. Santos, M. S Freitas, J. M. G. N. da Costa, and F. M D'Almeida Bernardo, "Mycobiota and aflatoxin B1 in feed for farmed sea bass (Dicentrarchus labrax)," Toxins, vol. 3, no. 3, pp. 163-171, 2011.

[11] J. W. Bennett and M. Klich, "Mycotoxins," Clinical Microbiology Reviews, vol. 16, no. 3, pp. 497-516, 2003.

[12] M. E. Zain, "Impact of mycotoxins on humans and animals," Journal of Saudi Chemical Society, vol. 15, no. 2, pp. 129-144, 2011.

[13] S. Bankole, M. Schollenberger, and W. Drochner, "Mycotoxins in food systems in sub saharan Africa: a review," Mycotoxin Research, vol. 22, no. 3, pp. 163-169, 2006.

[14] M. C. Chávez-Sánchez, C. A. Martínez Palacios, and I. Osorio Moreno, "Pathological effects of feeding young Oreochromis niloticus diets supplemented with different levels of aflatoxin B1," Aquaculture, vol. 127, no. 1, pp. 49-60, 1994.

[15] F. Berthiller, M. Sulyok, R. Krska, and R. Schuhmacher, "Chromatographic methods for the simultaneous determination of mycotoxins and their conjugates in cereals," International Journal of Food Microbiology, vol. 119, no. 1-2, pp. 33-37, 2007.

[16] J. I. Pitt, "Toxigenic fungi and mycotoxins," British Medical Bulletin, vol. 56, no. 1, pp. 184-192, 2000.

[17] W. L. Bryden, "Mycotoxin contamination of the feed supply chain: implications for animal productivity and feed security," Animal Feed Science and Technology, vol. 173, no. 1-2, pp. 134-158, 2012.
[18] Y. Huang, D. Han, X. Xiao et al., "Effect of dietary aflatoxin $\mathrm{B}_{1}$ on growth, fecundity and tissue accumulation in gibel carp during the stage of gonad development," Aquaculture, vol. 428-429, pp. 236-242, 2014.

[19] A. Cagauan and R. Tayaban, "Effect of aflatoxin-contaminated feeds in Nile tilapia (Oreochromis niloticus L.)," in Proceedings of the 6th International Symposium on Tilapia Aquaculture, pp. 172-178, Manila, Philippines, September 2004.

[20] M. E. Mahfouz and A. H. Sherif, "A multiparameter investigation into adverse effects of aflatoxin on Oreochromis niloticus health status," The Journal of Basic \& Applied Zoology, vol. 71, pp. 48-59, 2015.

[21] E. Marijani, J. Nasimolo, E. Kigadye, G. J. B. Gnonlonfin, and S. Okoth, "Sex-related differences in hematological parameters and organosomatic indices of Oreochromis niloticus exposed to aflatoxin $\mathrm{B}_{1}$ diet," Scientifica, vol. 2017, Article ID 4268926, p. 7, 2017.

[22] W. Jantrarotai and R. T. Lovell, "Subchronic toxicity of dietary aflatoxin $\mathrm{B}_{1}$ to channel catfish," Journal of Aquatic Animal Health, vol. 2, no. 4, pp. 248-254, 1990.

[23] M. P. Santacroce, M. C. Conversano, E. Casalino et al., "Aflatoxins in aquatic species: metabolism, toxicity and perspectives," Reviews in Fish Biology and Fisheries, vol. 18, no. 1, pp. 99-130, 2008.

[24] S. Craig and L. A. Helfrich, Understanding Fish Nutrition, Feeds, and Feeding, Virginia Cooperative Extension, Blacksburg, VA, USA, 2002.

[25] A. G. J. Tacon, Nutritional Fish Pathology: Morphological Signs of Nutrient Deficiency and Toxicity in Farmed Fish, Food and Agriculture Organization of the United Nations, Rome, Italy, 4th edition, 1992.

[26] H. Zhao, R. Jiang, M. Xue, S. Xie, X. Wu, and L. Guo, "Fishmeal can be completely replaced by soy protein concentrate by increasing feeding frequency in Nile tilapia (Oreochromis niloticus GIFT strain) less than 2 g," Aquaculture Nutrition, vol. 16, no. 6, pp. 648-653, 2010.

[27] C. C. Ngugi and J. O. Manyala, Aquaculture Extension in Sub-Saharan Africa, Food and Agriculture Organization, Rome, Italy, 2004.

[28] P. Spring, D. F. Fegan, T. P. Lyons et al., "Mycotoxins-a rising threat to aquaculture," in Proceedings of the Alltech's 23rd Annual Symposium, pp. 323-331, Alltech UK, Lexington, KY, USA, 2005.

[29] R. a. Samson, J. Houbraken, U. Thrane et al., "Food and Indoor Fungi," in CBS Lab. Man. Ser., A. Robert and C.-K. F. B. C. Samson, Eds., CBS-KNAW Fungal Biodiversity Centre, 2010.

[30] J. C. Frisvad, T. O. Larsen, U. Thrane et al., "Fumonisin and ochratoxin production in industrial Aspergillus niger strains," PLoS One, vol. 6, no. 8, Article ID e23496, 2011.

[31] K. J. Kwon-Chung and J. A. Sugui, "What do we know about the role of gliotoxin in the pathobiology of Aspergillus fumigatus?," Medical Mycology, vol. 47, pp. 97-103, 2009.

[32] B. L. Rao and A. Husain, "Presence of cyclopiazonic acid in kodo millet (Paspalum scrobiculatum) causing kodua poisoning in man and its production by associated fungi," Mycopathologia, vol. 89, no. 3, pp. 177-180, 1985.

[33] B. Caballero, P. Finglas, and F. Toldra, Encyclopedia of Food Sciences and Nutrition, Academic Press, Cambridge, MA, USA, 2nd edition, 2003.

[34] H. M. A. Mohamed, W. F. A. Emeish, A. Braeuning, and S Hammad, "Detection of aflatoxin-producing fungi isolated 
from Nile tilapia and fish feed," EXCLI Journal, vol. 16, pp. 1308-1318, 2017.

[35] E. Marijani, J. M. Wainaina, H. Charo-Karisa et al., "Mycoflora and mycotoxins in finished fish feed and feed ingredients from smallholder farms in East Africa," The Egyptian Journal of Aquatic Research, vol. 43, no. 2, pp. 169-176, 2017.

[36] G. Njagi, "Isolation of fungal agents from formulated and commercial feeds in three fish farms in humid tropical environments of Kenya," in Proceedings of the 5th Annual National Biosafety Conference, National Biosafety Authority, Nairobi, Kenya, August 2016.

[37] E. M. C. Gonçalves-Nunes, M. M. Gomes-Pereira, A. P. Raposo-Costa et al., "Screening of aflatoxin B1 and mycobiota related to raw materials and finished feed destined for fish," Latin American Journal of Aquatic Research, vol. 43, pp. 595-600, 2015.

[38] M. Greco, A. Pardo, and G. Pose, "Mycotoxigenic fungi and natural co-occurrence of mycotoxins in rainbow trout (Oncorhynchus mykiss) feeds," Toxins, vol. 7, no. 11, pp. 4595-4609, 2015.

[39] A. A. Fallah, E. Pirali-Kheirabadi, M. Rahnama, S. S. SaeiDehkordi, and K. Pirali-Kheirabadi, "Mycoflora, aflatoxigenic strains of Aspergillus section flavi and aflatoxins in fish feed," Quality Assurance and Safety of Crops \& Foods, vol. 6, no. 4, pp. 419-424, 2014.

[40] T. S. Barbosa, C. M. Pereyra, C. A. Soleiro et al., "Mycobiota and mycotoxins present in finished fish feeds from farms in the Rio de Janeiro State, Brazil," International Aquatic Research, vol. 5, no. 1, p. 3, 2013.

[41] F. D. C. C. Filho, R. M. Calvet, C. A. Da Rocha Rosa et al., "Monitoramento de fungos toxigênicos e aflatoxinas em rações utilizadas em piscicultura," Ciência Animal Brasileira, vol. 14, no. 3, pp. 305-311, 2013.

[42] C. H. Rodríguez-Cervantes, A. J. Ramos, M. L. RobledoMarenco, V. Sanchis, S. Marín, and M. I. Girón-Pérez, "Determination of aflatoxin and fumonisin levels through ELISA and HPLC, on tilapia feed in Nayarit, Mexico," Food and Agricultural Immunology, vol. 24, no. 3, pp. 269-278, 2013.

[43] S. Alinezhad, M. Tolouee, A. Kamalzadeh et al., "Mycobiota and aflatoxin $\mathrm{B}_{1}$ contamination of rainbow trout (Oncorhinchus mykiss) feed with emphasis to Aspergillus section Flavi. Iran," Journal of Fisheries Science, vol. 10, pp. 363-374, 2011.

[44] A. Hassan, M. El Shafei, M. S. El Ahl et al., "Detection of aflatoxigenic moulds isolated from fish and their products and its public health significance," Nature and Science, vol. 9, pp. 106-114, 2011.

[45] S. K. Mutiga, V. Hoffmann, J. W. Harvey, M. G. Milgroom, and R. J. Nelson, "Assessment of aflatoxin and fumonisin contamination of maize in Western Kenya," Phytopathology, vol. 105, no. 9, pp. 1250-1261, 2015.

[46] S. Yazar and G. Omurtag, "Fumonisins, trichothecenes and zearalenone in cereals," International Journal of Molecular Sciences, vol. 9, no. 11, pp. 2062-2090, 2008.

[47] D. Ivić, A.-M. Domijan, M. Peraica, T. Miličević, and B. Cvjetković, "Fusarium spp. contamination of wheat, maize, soybean, and pea in Croatia," Archives of Industrial Hygiene and Toxicology, vol. 60, no. 4, pp. 435-442, 2009.

[48] International Agency for Research on Cancer (IARC), Fungi Producing Significant Mycotoxins, International Agency for Research on Cancer, Lyon, France, 2012.
[49] J. Doughari, "The occurrence, properties and significance of citrinin mycotoxin," Journal of Plant Pathology \& Microbiology, vol. 6, no. 11, 2015.

[50] C. Schardl, "Introduction to the toxins special issue on ergot alkaloids," Toxins, vol. 7, no. 10, pp. 4232-4237, 2015.

[51] P. Skouboe, J. C. Frisvad, J. W. Taylor, D. Lauritsen, M. Boysen, and L. Rossen, "Phylogenetic analysis of nucleotide sequences from the ITS region of terverticillate Penicillium species," Mycological Research, vol. 103, no. 7, pp. 873-881, 1999.

[52] I. El-Kady, S. El-Maraghy, and A. N. Zohri, "Mycotoxin producing potential of some isolates of Aspergillus flavus and Eurotium groups from meat products," Microbiological Research, vol. 149, no. 3, pp. 297-307, 1994.

[53] M. V. Greco, A. G. Pardo, G. N. Pose, and A. R. Patriarca, "Efecto de la actividad del agua y la temperatura en el crecimiento de especies de Eurotium aisladas de alimentos para animales," Revista Iberoamericana de Micología, vol. 35, no. 1, pp. 39-48, 2018.

[54] A. Pittet, "Natural occurrence of mycotoxins in foods and feeds-an updated review," Revue De Medecine Veterinaire, vol. 149, pp. 479-492, 1998.

[55] K. R. N. Reddy, S. B. Nurdijati, and B. Salleh, "An overview of plant-derived products on control of mycotoxigenic fungi and mycotoxins," Asian Journal of Plant Sciences, vol. 9, no. 3, pp. 126-133, 2010.

[56] A. N. Kaaya and D. Eboku, "Mould and aflatoxin contamination of dried cassava chips in eastern Uganda: association with traditional processing and storage practices," Journal of Biological Sciences, vol. 10, no. 8, pp. 718-729, 2010.

[57] M. N. Sallam, Insect Damage: Damage on Post-Harvest, Food and Agriculture Organization, Rome, Italy, 1999.

[58] C. Thompson and S. E. Henke, "Effect of climate and type of storage container on aflatoxin production in corn and its associated risks to wildlife species," Journal of Wildlife Diseases, vol. 36, no. 1, pp. 172-179, 2000.

[59] D. L. Proctor, Grain Storage Techniques: Evolution and Trends in Developing Countries, Food and Agriculture Organization, Rome, Italy, 1994.

[60] H. K. Abbas, M. A. Weaver, R. M. Zablotowicz, B. W. Horn, and W. T. Shier, "Relationships between aflatoxin production and sclerotia formation among isolates of Aspergillus section Flavi from the Mississippi Delta," European Journal of Plant Pathology, vol. 112, no. 3, pp. 283-287, 2005.

[61] H. K. Abbas, R. D. Cartwright, W. T. Shier et al., "Natural occurrence of fumonisins in rice with Fusarium sheath rot disease," Plant Disease, vol. 82, no. 1, pp. 22-25, 1998.

[62] K. A. Scudamore, S. Nawaz, M. T. Hetmanski, and S. C. Rainbird, "Mycotoxins in ingredients of animal feeding stuffs: III. determination of mycotoxins in rice bran," Food Additives and Contaminants, vol. 15, no. 2, pp. 185-194, 1998.

[63] M. R. Laubscher, "Mycotoxin contamination of abalone feed: health and safety considerations for the abalone aquaculture industry," Ph. D. thesis, Stellenbosch University, Stellenbosch, South Africa, 2016.

[64] C. Pietsch, S. Kersten, P. Burkhardt-Holm, H. Valenta, and S. Dänicke, "Occurrence of deoxynivalenol and zearalenone in commercial fish feed: an initial study," Toxins, vol. 5, no. 1, pp. 184-192, 2013.

[65] E. W. Mwihia, P. G. Mbuthia, G. S. Eriksen et al., "Occurrence and levels of aflatoxins in fish feeds and their potential effects on fish in Nyeri, Kenya," Toxins, vol. 10, no. 12, p. 543, 2018. 
[66] Food and Drugs Authority, Chemical Contaminants, Metals, Natural Toxins \& Pesticides-Guidance for Industry and FDA: Advisory Levels for Deoxynivalenol (DON) in Finished Wheat Products for Human Consumption and Grains and Grain By-Products Used for Animal Feed, Center for Food Safety and Applied Nutrition, College Park, MD, USA, 2010.

[67] European Commission, "Recommendation of 17 August 2006 on the presence of deoxynivalenol, zearalenone, ochratoxin A, T-2 and HT-2 and fumonisins in products intended for animal feeding," Official Journal of the European Union, vol. L229/7-L229/9, 2006.

[68] S. A. Odoemelam and C. I. Osu, "Evaluation of the phytochemical content of some edible grains marketed in Nigeria," E-Journal of Chemistry, vol. 6, no. 4, pp. 1193-1199, 2009.

[69] M. Kholife, A. Moawad, A. M. Diab, and A. El-keredy, "Mycological examination of fish feed stuff with special reference to mycotoxin production," Slovenian Veterinary Research, vol. 56, no. 22, 2019.

[70] G. Altug and G. Beklevik, "Level of aflatoxin in some fish feeds from fish farming processes, feed factories and imported feeds," Turkish Journal of Veterinary and Animal Sciences, vol. 27, no. 6, pp. 1247-1252, 2003.

[71] E. H. Hashimoto, M. Kamogae, T. P. Vanzella et al., "Biomonitoring of microcystin and aflatoxin co-occurrence in aquaculture using immunohistochemistry and genotoxicity assays," Brazilian Archives of Biology and Technology, vol. 55, no. 1, pp. 151-159, 2012.

[72] M. Hussaini, D. Michael, N. Patrick, G. Timothy, and O. Godwin, "Aflatoxin contamination in foods and feeds: a special focus on Africa," in Trends in Vital Food and Control Engineering, pp. 187-234, Books on Demand, Norderstedt, Germany, 2012.

[73] I. Rodrigues, J. Handl, and E. M. Binder, "Mycotoxin occurrence in commodities, feeds and feed ingredients sourced in the Middle East and Africa," Food Additives and Contaminants: Part B, vol. 4, no. 3, pp. 168-179, 2011.

[74] J. A. Mmongoyo, F. Wu, J. E. Linz et al., "Aflatoxin levels in sunflower seeds and cakes collected from micro- and smallscale sunflower oil processors in Tanzania," PLoS One, vol. 12, no. 4, Article ID e0175801, 2017.

[75] J. H. Daniel, L. W. Lewis, Y. A. Redwood et al., "Comprehensive assessment of maize aflatoxin levels in eastern Kenya, 2005-2007," Environmental Health Perspectives, vol. 119, no. 12, pp. 1794-1799, 2011.

[76] K. R. N. Reddy and B. Salleh, "Co-occurrence of moulds and mycotoxins in corn grains used for Animal Feeds in Malaysia," Journal of Animal and Veterinary Advances, vol. 10, no. 5, pp. 668-673, 2011.

[77] P. Jayaraman and I. Kalyanasundaram, "Natural occurrence of toxigenic fungi and mycotoxins in rice bran," Mycopathologia, vol. 110, no. 2, pp. 81-85, 1990.

[78] F. Zaboli, A. R. Khosravi, I. Gholampourazizi et al., “A study of aflatoxins production in rice bran from Mazandran Province, Northern Iran," Global Veterinaria, vol. 5, no. 1, pp. 39-44, 2010.

[79] L. Pinotti, M. Ottoboni, C. Giromini, V. Dell'Orto, and F. Cheli, "Mycotoxin contamination in the EU feed supply chain: a focus on cereal byproducts," Toxins.vol. 8 , no. 2, p. $45,2016$.

[80] O. A. Daneil, O. Daneil Ochi, A. Adejumo et al., "Mycotoxicological concerns with sorghum, millet and sesame in Northern Nigeria," Journal of Analytical \& Bioanalytical Techniques, vol. 7, no. 5, 2016.
[81] E. Marijani, Occurrence of Mycotoxins in Fish Feeds and Fish with Special Regard to Aflatoxin Effect on Eggs and Milt Quality of Oreochromis niloticus, Open university of Tanzania, Dar es Salaam, Tanzania, 2018.

[82] J. B. Da Silva, C. R. Pozzi, M. A. B. Mallozzi, E. M. Ortega, and B. Corrêa, "Mycoflora and occurrence of aflatoxin $B_{1}$ and fumonisin $\mathrm{B}_{1}$ during storage of Brazilian sorghum," Journal of Agricultural and Food Chemistry, vol. 48, no. 9, pp. 4352-4356, 2000.

[83] P. H. Shetty and R. V. Bhat, "Natural occurrence of fumonisin Bland its Co-occurrence with aflatoxin B1in Indian sorghum, maize, and poultry feeds," Journal of Agricultural and Food Chemistry, vol. 45, no. 6, pp. 2170-2173, 1997.

[84] R. Bandyopadhyay, M. Kumar, and J. F. Leslie, "Relative severity of aflatoxin contamination of cereal crops in West Africa," Food Additives and Contaminants, vol. 24, no. 10, pp. 1109-1114, 2007.

[85] E. Streit, G. Schatzmayr, P. Tassis et al., "Current situation of mycotoxin contamination and co-occurrence in animal feed-focus on Europe," Toxins, vol. 4, no. 10, pp. 788-809, 2012.

[86] G. A. Santos, I. A. d. S. Rodrigues, K. Naehrer, and P. Encarnação, "Mycotoxins in aquaculture: occurrence in feed components and impact on animal performance," in Avances en Nutrición Acuícola X-Memorias del Décimo Simposio Internacional de Nutrició, pp. 502-513, Universidad Autónoma de Nuevo León, San Nicolás de los Garza, Mexico, 2010.

[87] C. Nyangi, "Aflatoxins and fumonisin contamination of marketed maize, maize bran and maize used as animal feed in Northern Tanzania," African Journal of Food, Agriculture, Nutrition and Development, vol. 16, no. 3, pp. 11054-11065, 2016.

[88] R. Gamanya and L. Sibanda, "Survey of Fusarium moniliforme (F. verticillioides) and production of fumonisin B1 in cereal grains and oilseeds in Zimbabwe," International Journal of Food Microbiology, vol. 71, no. 2-3, pp. 145-149, 2001.

[89] S. G. Edwards, E. T. Dickin, S. MacDonald et al., "Distribution of Fusarium mycotoxins in UK wheat mill fractions," Food Additives \& Contaminants: Part A, vol. 28, no. 12, pp. 1694-1704, 2011.

[90] M. F. Olorunfemi, A. C. Odebode, O. O. Olawuyi, and C. N. Ezekiel, "Multi-mycotoxin contaminations in fish feeds from different agro-ecological zones in Nigeria," in Proceedings of the Tropentag 2013 International Research on Food Security, Natural Resource Management and Rural Development, Stuttgart, Germany, September 2013.

[91] R. A. Gonçalves, K. Naehrer, and G. A. Santos, "Occurrence of mycotoxins in commercial aquafeeds in Asia and Europe: a real risk to aquaculture?," Reviews in Aquaculture, vol. 10, no. 2, pp. 263-280, 2018.

[92] H. H. L. Gonzalez, E. J. Martinez, A. M. Pacin, S. L. Resnik, and E. W. Sydenham, "Natural co-occurrence of fumonisins, deoxynivalenol, zearalenone and aflatoxins in field trial corn in Argentina," Food Additives and Contaminants, vol. 16, no. 12, pp. 565-569, 1999.

[93] C. M. Placinta, J. P. F. D’Mello, and A. M. C. MacDonald, “A review of worldwide contamination of cereal grains and animal feed with Fusarium mycotoxins," Animal Feed Science and Technology, vol. 78, no. 1-2, pp. 21-37, 1999.

[94] J. Pleadin, J. Frece, T. Lešić et al., "Deoxynivalenol and zearalenone in unprocessed cereals and soybean from 
different cultivation regions in Croatia," Food Additives \& Contaminants: Part B, vol. 10, pp. 1-7, 2017.

[95] S. Tola, D. Bureau, J. Hooft et al., "Effects of wheat naturally contaminated with Fusarium mycotoxins on growth performance and selected health indices of red Tilapia (Oreochromis niloticus $\times$ O. mossambicus)," Toxins, vol. 7, no. 6, pp. 1929-1944, 2015.

[96] M. Woźny, K. Obremski, E. Jakimiuk, M. Gusiatin, and P. Brzuzan, "Zearalenone contamination in rainbow trout farms in north-eastern Poland," Aquaculture, vol. 416-417, pp. 209-211, 2013.

[97] C. Lanier, N. Heutte, E. Richard, V. Bouchart, P. Lebailly, and D. Garon, "Mycoflora and mycotoxin production in oilseed cakes during farm storage," Journal of Agricultural and Food Chemistry, vol. 57, no. 4, pp. 1640-1645, 2009.

[98] Y. S. El-Sayed and R. H. Khalil, "Toxicity, biochemical effects and residue of aflatoxin B1 in marine water-reared sea bass (Dicentrarchus labrax L.)," Food and Chemical Toxicology, vol. 47, no. 7, pp. 1606-1609, 2009.

[99] H. Nomura, M. Ogiso, M. Yamashita et al., "Uptake by dietary exposure and elimination of aflatoxins in muscle and liver of rainbow trout (Oncorhynchus mykiss)," Journal of Agricultural and Food Chemistry, vol. 59, no. 9, pp. 51505158, 2011.

[100] J. M. Hooft, A. E. H. I. Elmor, P. Encarnação, and D. P. Bureau, "Rainbow trout (Oncorhynchus mykiss) is extremely sensitive to the feed-borne Fusarium mycotoxin deoxynivalenol (DON)," Aquaculture, vol. 311, no. 1-4, pp. 224-232, 2011.

[101] R. El-Banna, H. M. Teleb, M. M. Hadi, and F. M. Fakhry, "Performance and tissue residue of tilapias fed dietary aflatoxin," Veterinary Medical Journal, vol. 40, no. 3, pp. 17-23, 1992.

[102] N. A. Tuan, J. M. Grizzle, R. T. Lovell, B. B. Manning, and G. E. Rottinghaus, "Growth and hepatic lesions of Nile tilapia (Oreochromis niloticus) fed diets containing aflatoxin $\mathrm{B}_{1}$," Aquaculture, vol. 212, no. 1-4, pp. 311-319, 2002.

[103] S.-X. Deng, L.-X. Tian, F.-J. Liu et al., "Toxic effects and residue of aflatoxin B1 in tilapia (Oreochromis niloticus $\times O$. aureus) during long-term dietary exposure," Aquaculture, vol. 307 , no. 3-4, pp. 233-240, 2010.

[104] K. M. Selim, H. El-hofy, and R. H. Khalil, "The efficacy of three mycotoxin adsorbents to alleviate aflatoxin B1-induced toxicity in Oreochromis niloticus," Aquaculture International, vol. 22, no. 2, pp. 523-540, 2014.

[105] S. Lumlertdacha, R. T. Lovell, R. A. Shelby, S. D. Lenz, and B. W. Kemppainen, "Growth, hematology, and histopathology of channel catfish, Ictalurus punctatus, fed toxins from Fusarium moniliforme," Aquaculture, vol. 130, no. 2-3, pp. 201-218, 1995.

[106] P. K. Sahoo, S. K. Chattopadhyay, and A. Sikdar, "Immunosuppressive effects of induced alfatoxicosis in rabbits," Journal of Applied Animal Research, vol. 9, no. 1, pp. 17-26, 1996.

[107] S. Mohapatra, N. P. Sahu, A. K. Pal, A. K. Prusty, V. Kumar, and S. Kumar, "Haemato-immunology and histo-architectural changes in Labeo rohita fingerlings: effect of dietary aflatoxin and mould inhibitor," Fish Physiology and Biochemistry, vol. 37, no. 1, pp. 177-186, 2011.

[108] A. Sepahdari, H. A. Ebrahimzadeh Mosavi, I. Sharifpour et al., "Effects of different dietary levels of $\mathrm{AFB}_{1}$ on survival rate and growth factors of Beluga (Huso huso)," Iranian Journal of Fisheries Sciences, vol. 9, no. 1, pp. 141-150, 2010.

[109] N. A. Tuan, J. M. Grizzle, R. T. Lovell, B. B. Manning, and G. E. Rottinghaus, "Growth and hepatic lesions of Nile tilapia
(Oreochromis niloticus) fed diets containing aflatoxin B1," Aquaculture, vol. 212, no. 1-4, pp. 311-319, 2002.

[110] P. K. Sahoo and S. C. Mukherjee, "Immunosuppressive effects of aflatoxin $\mathrm{B}_{1}$ in Indian major carp (Labeo rohita)," Comparative Immunology, Microbiology and Infectious Diseases, vol. 24, no. 3, pp. 143-149, 2001.

[111] B. B. Manning, R. M. Ulloa, M. H. Li, E. H. Robinson, and G. E. Rottinghaus, "Ochratoxin A fed to channel catfish (Ictalurus punctatus) causes reduced growth and lesions of hepatopancreatic tissue," Aquaculture, vol. 219, no. 1-4, pp. 739-750, 2003.

[112] B. B. Manning, J. S. Terhune, M. H. Li, E. H. Robinson, D. J. Wise, and G. E. Rottinghaus, "Exposure to feedborne mycotoxins T-2 toxin or ochratoxin a causes increased mortality of channel catfish challenged with Edwardsiella ictaluri," Journal of Aquatic Animal Health, vol. 17, no. 2, pp. 147-152, 2005.

[113] K. Supamattaya, N. Sukrakanchana, M. Boonyaratpalin et al., "Effects of ochratoxin A and deoxynivalenol on growth performance and immuno-physiological parameters in black tiger shrimp (Penaeus monodon)," Songklanakarin Journal of Science and Technology, vol. 27, pp. 91-99, 2005.

[114] M. A. Abdel-Wahhab, A. M. Hasan, S. E. Aly, and K. F. Mahrous, "Adsorption of sterigmatocystin by montmorillonite and inhibition of its genotoxicity in the Nile tilapia fish (Oreachromis nilaticus)," Mutation Research/ Genetic Toxicology and Environmental Mutagenesis, vol. 582, no. 1-2, pp. 20-27, 2005.

[115] K. F. Mahrous, W. K. B. Khalil, and M. A. Mahmoud, "Assessment of toxicity and clastogenicity of sterigmatocystin in Egyptian Nile tilapia," African Journal of Biotechnology, vol. 5, pp. 1180-1189, 2006.

[116] G. S. Bbosa, D. Kitya, J. Odda, and J. Ogwal-Okeng, "Aflatoxins metabolism, effects on epigenetic mechanisms and their role in carcinogenesis," Health, vol. 5, no. 10, pp. 14-34, 2013.

[117] A. Diab, "Effect of aflatoxin $B_{1}$ on reproductive traits in Oreochromis niloticus and Oreochromis aureus and its control," in Proceedings of the 5th 5th International Symposium on Tilapia Aquaculture, pp. 465-473, Rio de Janeiro, Brazil, 2000.

[118] S. Döll, H. Valenta, G. Baardsen et al., "Effects of increasing concentrations of deoxynivalenol, zearalenone and ochratoxin A in diets for Atlantic Salmon (Salmo salar) on performance, health and toxin residues," in Proceedings of the Abstracts of the 33rd Mycotoxin Workshop, pp. 25-30, Society for Mycotoxin Research, Freising, Germany, 2011.

[119] B. B. Manning, H. K. Abbas, D. J. Wise et al., "The effect of feeding diets containing deoxynivalenol contaminated corn on channel catfish (Ictalurus punctatus) challenged with Edwardsiella ictaluri," Aquaculture Research, vol. 45, pp. 1782-1786, 2013.

[120] B. B. Manning, M. H. Li, E. H. Robinson, P. S. Gaunt, A. C. Camus, and G. E. Rottinghaus, "Response of channel catfish to diets containing T-2 toxin," Journal of Aquatic Animal Health, vol. 15, no. 3, pp. 229-238, 2003.

[121] M. Yildirim, B. B. Manning, R. T. Lovell, J. M. Grizzle, and G. E. Rottinghaus, "Toxicity of moniliformin and fumonisin B1 fed singly and in combination in diets for young channel catfish Ictalurus punctatus," Journal of the World Aquaculture Society, vol. 31, no. 4, pp. 599-608, 2007.

[122] N. A. Tuan, B. B. Manning, R. T. Lovell, and G. E. Rottinghaus, "Responses of Nile tilapia (Oreochromis niloticus) fed diets containing different concentrations of moniliformin or 
fumonisin B1,” Aquaculture, vol. 217, no. 1-4, pp. 515-528, 2003.

[123] D. B. Carlson, D. E. Williams, J. M. Spitsbergen et al., "Fumonisin B1 promotes aflatoxin B1 and N-methyl-N'nitro-nitrosoguanidine-Initiated liver tumors in rainbow trout," Toxicology and Applied Pharmacology, vol. 172, no. 1, pp. 29-36, 2001.

[124] Z. Petrinec, S. Pepeljnjak, S. Kovacic et al., "Fumonisin $B_{1}$ causes multiple lesions in common carp (Cyprinus carpio)," Deutsche Tierärztliche Wochenschrift, vol. 111, pp. 358-363, 2004.

[125] S. Pepeljnjak, Z. Petrinec, S. Kovacic, and M. Segvic, "Screening toxicity study in young carp (Cyprinus carpio L.) on feed amended with fumonisin $\mathrm{B}_{1}$," Mycopathologia, vol. 156, no. 2, pp. 139-145, 2003.

[126] P. Schwartz, K. L. Thorpe, T. D. Bucheli, F. E. Wettstein, and P. Burkhardt-Holm, "Short-term exposure to the environmentally relevant estrogenic mycotoxin zearalenone impairs reproduction in fish," Science of The Total Environment, vol. 409, no. 2, pp. 326-333, 2010.

[127] P. Schwartz, T. D. Bucheli, F. E. Wettstein, and P. BurkhardtHolm, "Life-cycle exposure to the estrogenic mycotoxin zearalenone affects zebrafish (Danio rerio) development and reproduction," Environmental Toxicology, vol. 28, no. 5, pp. 276-289, 2013.

[128] O. Bundit, W. Phromkunthong, H. Kanghae, and K. Supamattaya, "Effects of mycotoxin T-2 and zearalenone on histopathological changes in black tiger shrimp (Penaeus monodon Fabricius)," Songklanakarin Journal of Science and Technology, vol. 28, no. 5, 2006.

[129] C. Pietsch, S. Kersten, H. Valenta et al., "Effects of dietary exposure to zearalenone (ZEN) on carp (Cyprinus carpio L.)," Toxins, vol. 7, no. 9, pp. 3465-3480, 2015.

[130] M. Woźny, S. Dobosz, K. Obremski et al., "Feed-borne exposure to zearalenone leads to advanced ovarian development and limited histopathological changes in the liver of premarket size rainbow trout," Aquaculture, vol. 448, pp. 71-81, 2015.

[131] F. I. Meredith, R. T. Riley, C. W. Bacon, D. E. Williams, and D. B. Carlson, "Extraction, quantification, and biological availability of fumonisin B1 incorporated into the oregon test diet and fed to rainbow trout," Journal of Food Protection, vol. 61, no. 8, pp. 1034-1038, 1998.

[132] C. Pietsch, C. Michel, S. Kersten et al., "In vivo effects of deoxynivalenol (DON) on innate immune responses of carp (Cyprinus carpio L.)," Food and Chemical Toxicology, vol. 68, pp. 44-52, 2014.

[133] M. Sanden, S. Jørgensen, G.-I. Hemre, R. Ørnsrud, and N. H. Sissener, "Zebrafish (Danio rerio) as a model for investigating dietary toxic effects of deoxynivalenol contamination in aquaculture feeds," Food and Chemical Toxicology, vol. 50, no. 12, pp. 4441-4448, 2012.

[134] F. Minervini and M. E. Dell'Aquila, "Zearalenone and reproductive function in farm animals," International Journal of Molecular Sciences, vol. 9, no. 12, pp. 2570-2584, 2008.

[135] K. Bakos, R. Kovács, Á. Staszny et al., “Developmental toxicity and estrogenic potency of zearalenone in zebrafish (Danio rerio)," Aquatic Toxicology, vol. 136-137, pp. 13-21, 2013.

[136] A. M. E. Shalaby, "The opposing effect of ascorbic acid (vitamin C) on ochratoxin toxicity in Nile tilapia (Oreochromis niloticus)," in Proceedings of the 6th International Symposium on Tilapia in Aquaculture, pp. 209-221, Manila, Philippines, September 2004.
[137] I. Andretta, M. Kipper, C. R. Lehnen, L. Hauschild, M. M. Vale, and P. A. Lovatto, "Meta-analytical study of productive and nutritional interactions of mycotoxins in growing pigs," Animal, vol. 6, no. 9, pp. 1476-1482, 2012.

[138] P. B. Njobeh, M. F. Dutton, A. T. Åberg, and P. Haggblom, "Estimation of multi-mycotoxin contamination in South African compound feeds," Toxins, vol. 4, no. 10, pp. 836-848, 2012.

[139] C.-H. He, Y.-H. Fan, Y. Wang, C.-Y. Huang, X.-C. Wang, and H.-B. Zhang, "The individual and combined effects of deoxynivalenol and aflatoxin B1 on primary hepatocytes of Cyprinus carpio," International Journal of Molecular Sciences, vol. 11, no. 10, pp. 3760-3768, 2010.

[140] C. McKean, L. Tang, M. Tang et al., "Comparative acute and combinative toxicity of aflatoxin B1 and fumonisin B1 in animals and human cells," Food and Chemical Toxicology, vol. 44, no. 6, pp. 868-876, 2006.

[141] L. Afsah-Hejri, S. Jinap, P. Hajeb, S. Radu, and S. Shakibazadeh, "A review on mycotoxins in food and feed: Malaysia case study," Comprehensive Reviews in Food Science and Food Safety, vol. 12, no. 6, pp. 629-651, 2013.

[142] R. B. Harvey, T. S. Edrington, L. F. Kubena, and G. E. Rottinghaus, "Influence of aflatoxin and fumonisin $\mathrm{B}_{1}$ containing culture material on growing barrows," American Journal of Veterinary Research, vol. 56, no. 12, pp. 1668-1672, 1995.

[143] M. C. Smith, S. Madec, E. Coton et al., "Natural co-occurrence of mycotoxins in foods and feeds and their in vitro combined toxicological effects," Toxins, vol. 8, no. 4, p. 94, 2016.

[144] J. Verma, T. S. Johri, and B. K. Swain, "Effect of aflatoxin, ochratoxin and their combination on protein and energy utilisation in white leghorn laying hens," Journal of the Science of Food and Agriculture, vol. 87, no. 5, pp. 760-764, 2007.

[145] M. N. Bautista, C. R. Lavilla-Pitogo, P. F. Subosa, and E. T. Begino, "Aflatoxin B1 contamination of shrimp feeds and its effect on growth and hepatopancreas of pre-adult Penaeus monodon," Journal of the Science of Food and Agriculture, vol. 65, no. 1, pp. 5-11, 1994. 


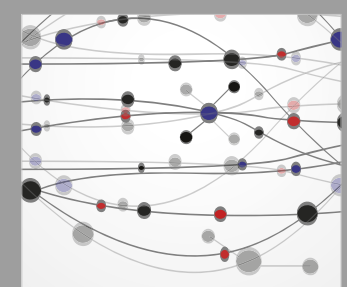

The Scientific World Journal
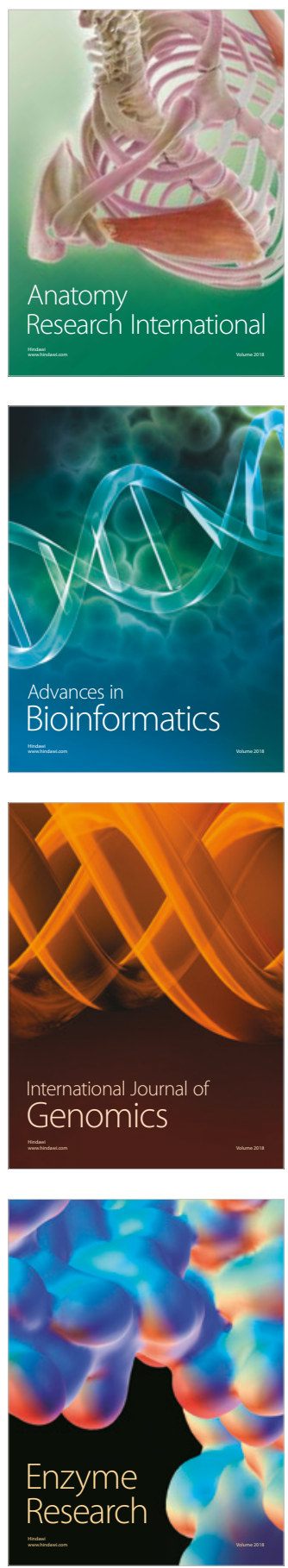
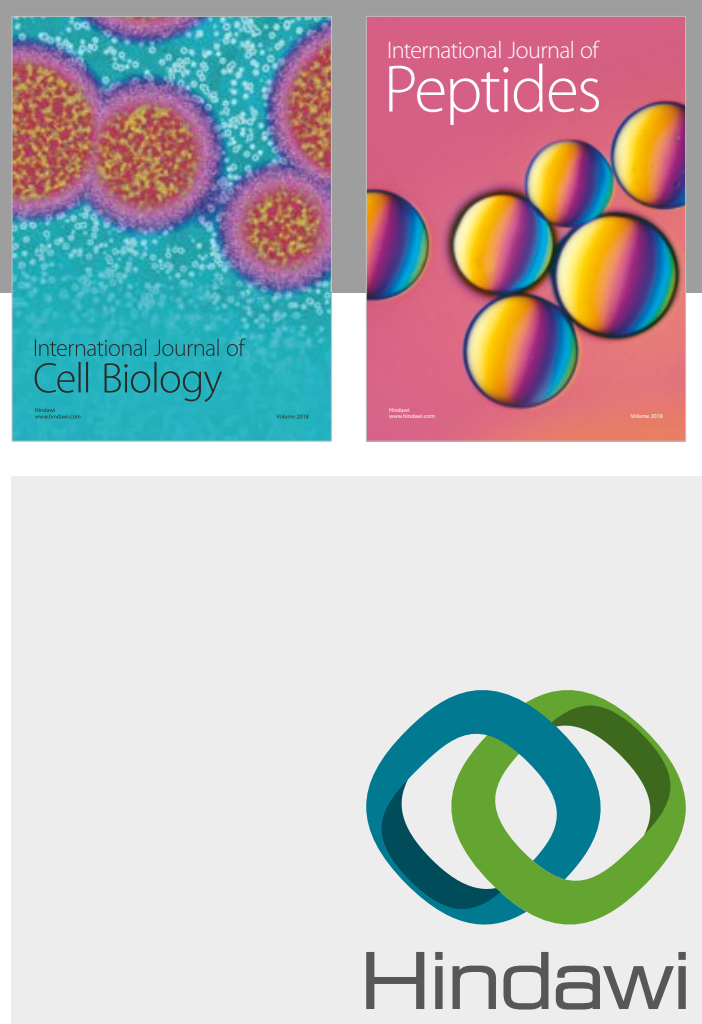

Submit your manuscripts at

www.hindawi.com
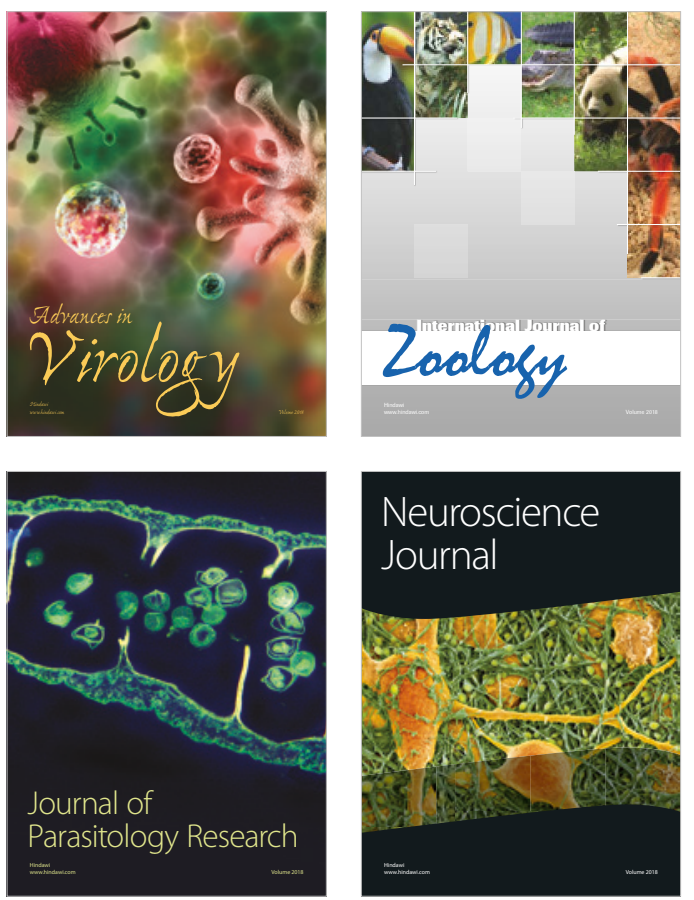
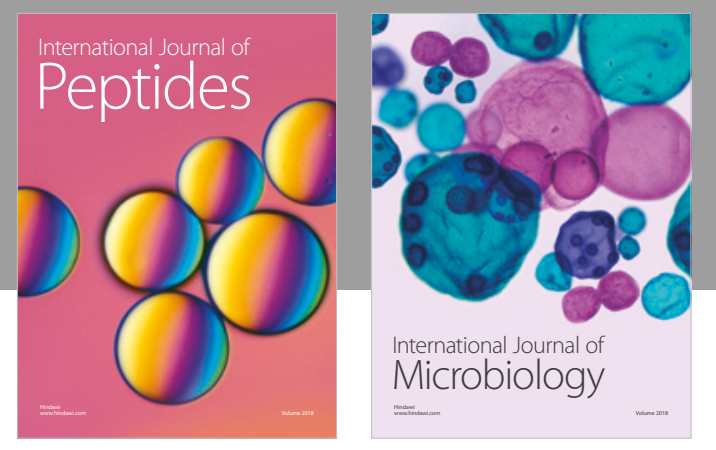

nternational Journal of Microbiology
Journal of
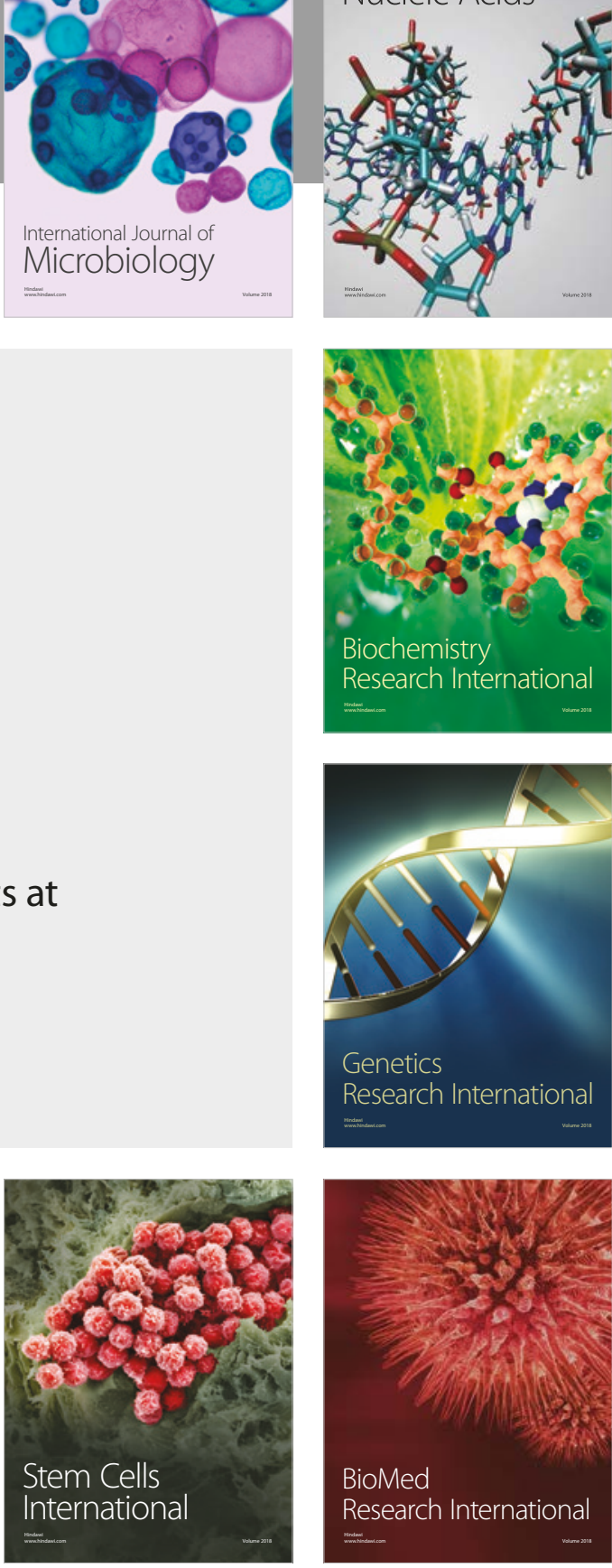
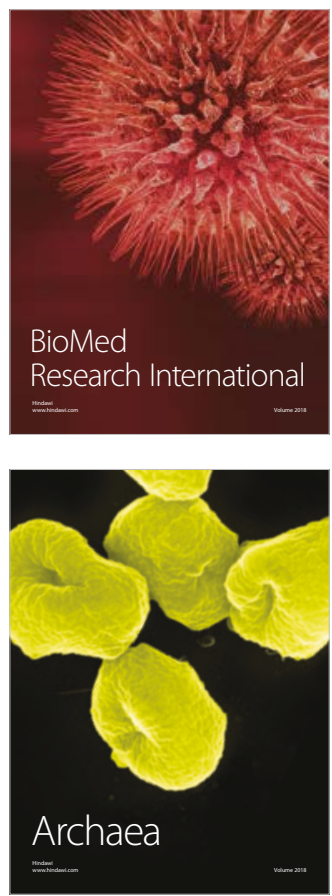